\title{
S-SCAM, A Rare Copy Number Variation Gene, Induces Schizophrenia-Related Endophenotypes in Transgenic Mouse Model
}

\author{
Nanyan Zhang, ${ }^{1}$ Peng Zhong, ${ }^{1}$ Seung Min Shin, ${ }^{1}$ Jacob Metallo, ${ }^{1}$ Eric Danielson, ${ }^{1}{ }^{\circledR}$ Christopher M. Olsen, ${ }^{1,2}$ \\ Qing-song Liu, ${ }^{1,2}$ and Sang H. Lee ${ }^{1,2}$ \\ ${ }^{1}$ Department of Pharmacology and Toxicology, and ${ }^{2}$ Neuroscience Research Center, Medical College of Wisconsin, Milwaukee, Wisconsin 53226
}

\begin{abstract}
Accumulating genetic evidence suggests that schizophrenia (SZ) is associated with individually rare copy number variations (CNVs) of diverse genes, often specific to single cases. However, the causality of these rare mutations remains unknown. One of the rare CNVs found in SZ cohorts is the duplication of Synaptic Scaffolding Molecule (S-SCAM, also called MAGI-2), which encodes a postsynaptic scaffolding protein controlling synaptic AMPA receptor levels, and thus the strength of excitatory synaptic transmission. Here we report that, in a transgenic mouse model simulating the duplication conditions, elevation of S-SCAM levels in excitatory neurons of the forebrain was sufficient to induce multiple SZ-related endophenotypes. S-SCAM transgenic mice showed an increased number of lateral ventricles and a reduced number of parvalbumin-stained neurons. In addition, the mice exhibited SZ-like behavioral abnormalities, including hyperlocomotor activity, deficits in prepulse inhibition, increased anxiety, impaired social interaction, and working memory deficit. Notably, the S-SCAM transgenic mice showed a unique sex difference in showing these behavioral symptoms, which is reminiscent of human conditions. These behavioral abnormalities were accompanied by hyperglutamatergic function associated with increased synaptic AMPA receptor levels and impaired long-term potentiation. Importantly, reducing glutamate release by the group 2 metabotropic glutamate receptor agonist LY379268 ameliorated the working memory deficits in the transgenic mice, suggesting that hyperglutamatergic function underlies the cognitive functional deficits. Together, these results contribute to validate a causal relationship of the rare S-SCAM CNV and provide supporting evidence for the rare CNV hypothesis in SZ pathogenesis. Furthermore, the S-SCAM transgenic mice provide a valuable new animal model for studying SZ pathogenesis.
\end{abstract}

Key words: animal model; CNV; glutamatergic; S-SCAM/MAGI-2; schizophrenia; sexual dimorphism

\section{Introduction}

Schizophrenia (SZ) is a devastating psychiatric disorder that affects nearly $1 \%$ of populations worldwide. SZ is characterized by the manifestation of common symptoms of positive (hallucinations, delusion, and disorganized thought), negative (social withdrawal, apathy, and emotional blunting), and cognitive dysfunction (deficits in working memory, attention, and executive function; Pearlson, 2000; Nuechterlein et al., 2004; Tandon et al., 2009). One of the more consistently reported clinical aspects of SZ is gender difference, which exists in most features of the illness (Abel et al., 2010). Typically, men show a higher incidence $(\sim 1.5$-fold $)$ and experience a more severe course of the disease, as shown by the

Received Sept. 2, 2014; revised Dec. 10, 2014; accepted Dec. 11, 2014.

Author contributions: N.Z. and S.H.L. designed research;N.Z., P.Z.,S.M.S., J.M., and E.D. performed research;N.Z., P.Z., S.M.S., C.M.O., Q.-s.L., and S.H.L. analyzed data; N.Z., C.M.O., and S.H.L. wrote the paper.

This work was supported by a National Institutes of Health grant and by funding provided through the Research and Education Program, a component of the Advancing a Healthier Wisconsin endowment at the Medical College of Wisconsin.

The authors declare no competing financial interests.

Correspondence should be addressed to Dr. Sang H. Lee, Department of Pharmacology and Toxicology, Medical College of Wisconsin, 8701 Watertown Plank Road, Milwaukee, WI 53226. E-mail: shlee@mcw.edu.

DOI:10.1523/JNEUROSCI.3658-14.2015

Copyright $\odot 2015$ the authors $\quad 0270-6474 / 15 / 351892-13 \$ 15.00 / 0$ earlier onset of disease symptoms, more severe deficits in cognitive function, and poorer prognosis. Conversely, women with SZ function at relatively higher levels and show better responses to treatments. Physiological bases of the sex difference remain unclear, but accumulating evidence suggests a protective role of estrogens against this disorder (Begemann et al., 2012; Wu et al., 2013).

SZ has a strong genetic component. Linkage and candidate gene association studies have identified several genes, including Neuregulin 1 (NRG1; Stefansson et al., 2002), ErbB4 (Mei and Xiong, 2008), and Disrupted In Schizophrenia (DISC1; Millar et al., 2000). The causality of these susceptibility genes has been established by multiple lines of genetic animal models showing SZ-related endophenotypes (Jones et al., 2011). However, these mutations have low prevalence and are associated with specific populations, indicating the genetically heterogeneous nature of the disease (Mowry and Gratten, 2013). Recent genome-wide genetic studies lend strong support to the hypothesis that individually rare copy number variations (CNVs) of various genes contribute to SZ pathogenesis (Walsh et al., 2008; Karlsson et al., 2012). However, genetic animal models addressing the causality of rare CNVs have not been reported.

A duplication of the Synaptic Scaffolding Molecule (S-SCAM) gene is one of the rare CNVs found in SZ (Walsh et al., 2008). 
S-SCAM is a scaffolding protein involved in the synaptic protein organization and plays an essential role in the maintenance of AMPA receptors at synapses (Hirao et al., 1998; Stan et al., 2010; Danielson et al., 2012). S-SCAM interacts with various synaptic proteins including neuroligins (Sumita et al., 2007) and ErbB4 (Buxbaum et al., 2008). Notably, mutations in ErbB4 and neuroligins are also found in SZ (Mei and Xiong, 2008; Sun et al., 2011). In addition, common variants (single nucleotide polymorphisms) in S-SCAM genes are associated with increased risk for cognitive impairment in individuals with SZ (Koide et al., 2012). Therefore, considering these facts, it is likely that the $\mathrm{S}-\mathrm{SCAM}$ gene mutations contribute to the pathogenesis of SZ. To test the hypothesis, we generated a transgenic (Tg) mouse model that overexpresses S-SCAM, mimicking the human conditions of S-SCAM gene duplication.

In the present study, we report that the S-SCAM Tg mice exhibit morphological features and sex-dependent selective behavioral deficits, which are reminiscent of SZ. We also show that hyperglutamatergic function and impaired long-term potentiation (LTP) are associated with the cognitive deficits in the mutant mice. Therefore, these results suggest that S-SCAM gene duplication in humans has relevance to $\mathrm{SZ}$ pathogenesis.

\section{Materials and Methods}

Transgene construction and generation of S-SCAM Tg mice For generation of CaMKII $\alpha-S$-SCAM transgene construct, a $3.9 \mathrm{~kb}$ mycS-SCAM cDNA fragment was first cloned into the EcoRV and SphI sites of pNN265 vector to add a $5^{\prime}$ intron and a $3^{\prime}$ intron plus a poly(A) signal from SV40. A $5.3 \mathrm{~kb}$ NotI fragment from the myc-S-SCAM/pNN265 plasmid was cloned into the NotI site of pMM403, which contains the 8.5 $\mathrm{kb}$ of the mouse CaMKII $\alpha$ promoter. After SfiI digestion, a $13.8 \mathrm{~kb}$ linearized fragment was gel purified and injected into C57BL/6J oocytes to generate Tg mice ( performed by The Jackson Laboratory). The Tg founders were bred with wild-type (WT) C57BL/6 J mice. All experimental procedures involving the mice were approved by the Institutional Animal Care and Use Committee of the Medical College of Wisconsin.

Genotyping of Tg Mice by PCR

Genomic tail DNA was used for genotyping Tg animals by PCR. The following primers were used: forward primer $5^{\prime}$-AAG CTC GTC AGT CAA GCC GGT TC- $3^{\prime}$ at position -139 of the first ATG in the CaMKII $\alpha$ gene; and reverse primer 5'-GCA GGT CCT CCT CGC TGA TAA GC-3' targeting the myc tag on the transgene, resulting in a $470 \mathrm{bp}$ band. As a positive control for PCR on genomic DNA, primers for the murine interleukin-2 precursor gene were mixed into the reaction, resulting in a 320 bp band (forward primer 5'-CTA GGC CAC AGA ATT GAA AGA TCT-3'; reverse primer $5^{\prime}$-GTA GGT GGA AAT TCT AGC ATC ATC C-3'). The PCR conditions were as follows: $94^{\circ} \mathrm{C}$ for $30 \mathrm{~s}, 55^{\circ} \mathrm{C}$ for $30 \mathrm{~s}$, and $72^{\circ} \mathrm{C}$ for $30 \mathrm{~s}$, for 35 cycles.

\section{Histological staining}

Four-month-old mice were anesthetized and perfused transcardially in PBS with $4 \%$ paraformaldehyde and $4 \%$ sucrose. The brains were removed and post-fixed in the same perfusion solution overnight, then immersed sequentially in a $20 \%$ sucrose solution for $6 \mathrm{~h}$ and a $30 \%$ sucrose solution overnight. The tissues were mounted in Tissue-Tek O.C.T. compound and sliced with a cryostat into $30-\mu \mathrm{m}$-thick sections. Some sections were stained with cresyl violet to evaluate histopathology of the brain. Adjacent sections were used for immunostaining. For immunofluorescence, the sections were incubated with mouse antiparvalbumin (PV; 1:1000, clone PARV-19; Sigma) and rabbit anti-NeuN antibodies (1:400; Millipore) or rabbit anti-vasoactive intestinal peptide (VIP; 1:200; Immunostar) overnight at $4^{\circ} \mathrm{C}$. The sections were then incubated with Alexa Fluor 488 (1:250; Invitrogen) and Cy3-conjugated (1:400; Jackson ImmunoResearch) secondary antibodies. For lateral ventricle (LV) size analysis, serial coronal sections (two to three per animal) of cresyl violet-stained brains $(0.1 \pm 0.05 \mathrm{~mm}$ from bregma) were used for calculating the average LV area, in which the largest LV areas in the mouse brain atlas are shown. The LV area was determined by tracing the edge of the LV using MetaMorph software (Molecular Devices), and the combined area sizes of two LVs (left and right) were used for analysis. The numbers of PV-stained and $\mathrm{NeuN}$-stained cells were determined by averaging the number of cells in the designated areas $(\sim 0.1$ $\mathrm{mm}^{2}$ for CA1 and CA3; $\sim 0.4 \mathrm{~mm}^{2}$ for cortex) of two adjacent brain sections $(-1.7 \pm 0.2 \mathrm{~mm}$ from bregma) per animal.

\section{1,1'-Dioctadecyl-3,3,3',3' -tetramethylindocarbocyanine perchlorate labeling}

Two-month-old mice were anesthetized and perfumed transcardially with $1.5 \%$ paraformaldehyde in PBS. The brains were removed and postfixed in the same solution for $1 \mathrm{~h}$. Vibratome sections of $250 \mu \mathrm{m}$ were prepared and subjected to "Diolistic" labeling. The $1.7 \mu \mathrm{m}$ tungsten beads (Bio-Rad) were coated with 1,1'-dioctadecyl-3,3,3',3'-tetramethylindocarbocyanine perchlorate (DiI) crystals (Invitrogen) and shot into fixed sections with a Helios gene gun (Bio-Rad). Sections were kept in PBS at room temperature (RT) for $24 \mathrm{~h}$, and then post-fixed in $4 \%$ paraformaldehyde in PBS at RT for $1 \mathrm{~h}$ and mounted for confocal microscopy. Spine densities were analyzed from the secondary branches of apical dendrites of neurons that are at similar distances from the soma. Spine density was calculated by taking an average value measured from 10 to 24 dendritic segments ( $\sim 20 \mu \mathrm{m}$ in length) per each brain region of an animal.

\section{Confocal microscopy and image analyses}

Image acquisition was performed using a Nikon C1 plus laser scanning confocal microscope with a $60 \times$ objective lens (numerical aperture 1.4). Acquired $z$-series stack images were converted to projection images (with maximal projection option) for analysis using MetaMorph software or in-house custom-written software. Images were analyzed in a doubleblind manner.

\section{Electrophysiology}

Transverse hippocampal slices (300 $\mu \mathrm{m}$ thick) were prepared as described previously (Pan et al., 2009). Briefly, after decapitation, slices were prepared at $4-6^{\circ} \mathrm{C}$ in a solution containing the following (in $\mathrm{mM}$ ): 220 sucrose, $2.5 \mathrm{KCl}, 1.25 \mathrm{NaH}_{2} \mathrm{PO}_{4}, 0.5 \mathrm{CaCl}_{2}, 7 \mathrm{MgSO}_{4}, 26 \mathrm{NaHCO}_{3}$, 10 glucose, and 1 sodium ascorbate. The slices were transferred to and stored in artificial CSF (in mm: $119 \mathrm{NaCl}, 2.5 \mathrm{KCl}, 2.5 \mathrm{CaCl}_{2}, 1 \mathrm{MgCl}_{2}$, $1.25 \mathrm{NaH}_{2} \mathrm{PO}_{4}, 26 \mathrm{NaHCO}_{3}, 10$ glucose) at room temperature for $>1 \mathrm{~h}$ before recordings were made. All solutions were saturated with $95 \% \mathrm{O}_{2}$ and $5 \% \mathrm{CO}_{2}$. Field EPSPs (fEPSPs) recordings were made by placing a glass pipette filled with the $1 \mathrm{M} \mathrm{NaCl}(1-2 \mathrm{M} \Omega$ ) in the stratum radiatum of the CA1 region of the hippocampal slices, and fEPSPs were evoked by stimulation of the Schaffer collateral/commissural pathway with a bipolar tungsten electrode (WPI). Input-output curves were generated by plotting the fEPSP slope against the presynaptic fiber volley amplitude following incremental stimulus intensities. For LTP experiments, stable baseline fEPSPs were recorded for at least $30 \mathrm{~min}$ at an intensity that induced $\sim 40 \%$ of the maximal evoked response. High-frequency stimulation (two trains of $100 \mathrm{~Hz}$ for $1 \mathrm{~s}$ with $20 \mathrm{~s}$ intertrain intervals) was used to induce LTP. All recordings were performed at $32 \pm 1^{\circ} \mathrm{C}$ by using an automatic temperature controller.

\section{Statistical analysis}

When comparing data from two groups, an unpaired $t$ test, assuming unequal variance, was used. For behavioral analyses, two-way ANOVA and Tukey's post hoc test were used. Statistical significance was set at $\alpha=$ 0.05 . Data were presented as the mean \pm SEM, and $n$ represents the number of animals used in each group.

\section{Western blotting}

For analysis of levels of different proteins, the forebrains for 4-month-old mice were homogenized in buffered sucrose $(0.32 \mathrm{M}$ sucrose, $4 \mathrm{~mm}$ HEPES, pH 7.4, 1 mм $\mathrm{MgCl}_{2}, 0.5 \mathrm{~mm} \mathrm{CaCl} 2,0.5$ mм DTT, 1 mм PMSF, and complete protease inhibitor mixture; Roche). Homogenates were spun $10 \mathrm{~min}$ at $800 \times g$, and the resulting supernatant was spun for 15 $\mathrm{min}$ at $9200 \times g$. The pellet was collected as a synaptosomal fraction and resuspended in buffered sucrose. The proteins were then resolved by $7 \%$ 
or $10 \%$ SDS-PAGE, transferred to a PVDF membrane, and probed with the following antibodies: mouse anti-myc (clone 9E10; Santa Cruz Biotechnology), rabbit anti-MAGI2 (Sigma), mouse anti-NSF (clone NSF-1; Calbiochem), mouse anti-pan-SAPAP [clone N127/31; University of California, Davis (UCDavis) /National Institutes of Health (NIH) NeuroMab], mouse anti-pan-Shank (clone N23B49; UCDavis/NIH Neuro$\mathrm{Mab}$ ), mouse anti-PSD95 (clone K28/43; UCDavis/NIH NeuroMab), rabbit anti-GluA1 (Calbiochem), rabbit anti-GluA2/3 (Millipore Bioscience Research Reagents), mouse anti-NMDAR1 (BD PharMingen), mouse anti-NMDAR2B (clone N59/36; UCDavis/NIH NeuroMab), rabbit anti-ErbB4 (C18, sc-283, Santa Cruz Biotechnology), and rabbit-antiGAPDH (D16H11; Cell Signaling Technology).

\section{Behavioral tests}

All behavioral tests were performed with age-matched littermates of 3- to 5-month-old animals of either sex.

Open field test. Each individual mouse was placed at the center of a circular arena (50 cm diameter), and the movement of the mouse was recorded for $30 \mathrm{~min}$ by a video camera controlled by the Ethovision XT 8 program (Noldus Inc.).

Elevated plus maze test. The maze consists of four arms in the form of a plus sign: two open arms $(30 \times 5 \mathrm{~cm})$ and two closed arms of the same size, also with an open roof, but enclosed by a wall (15 cm high). The maze is elevated $40 \mathrm{~cm}$ above the floor. Each mouse was placed in the center of $(5 \times 5 \mathrm{~cm})$ of the maze facing one of the open arms. During the $5 \mathrm{~min}$ test period, the movement of the mouse was recorded by a video camera, mounted centrally above the plus maze, controlled by the Ethovision XT 8 program.

Three-chamber social preference test. The apparatus is a rectangular, three-chamber box made from clear Plexiglas. Each chamber measures $20 \mathrm{~cm}$ (length) $\times 40 \mathrm{~cm}$ (width) $\times 22 \mathrm{~cm}$ (height). Each dividing wall has a square opening $(5 \times 8 \mathrm{~cm})$ to allow access into each chamber. A cylindrical wire cage (galaxy pencil cup, $7 \mathrm{~cm}$ diameter) was used as an inanimate object. In the first $10 \mathrm{~min}$ session, the test mouse was placed in the center of the empty three-chamber box for habituation. The mouse was allowed to freely explore each chamber. In the second 10 min session, an age- and gender-matched C57BL/6J mouse (S1) that had never been exposed to the test mouse was placed in one of the two wire cages. The wire cage on the other side remained empty. Then the test mouse was placed in the center and allowed to freely explore the chamber for $10 \mathrm{~min}$. In the last 10 min session, a second age- and gender-matched C57BL/6J stranger mouse that had never been exposed to the test mouse was placed in one wire cage, which previously served as an empty cage. The test mouse was placed in the center and allowed to freely explore the chamber for $10 \mathrm{~min}$. Now the test mouse would have the choice between a mouse that was already familiar (S1) and a new stranger mouse (S2). The movement of the mouse was recorded by a video camera controlled by the Ethovision XT 8 program.

Nesting behavior test. Mice were housed individually and provided with cotton nestlet square $(5 \times 5 \mathrm{~cm}$; Ancare $) 1 \mathrm{~h}$ before the onset of the dark phase. Nests were assessed on next morning, and the quality of the nest was scored on a 5-point rating scale based upon the scale of Deacon (2006) as follows: (1) the nestlet did not noticeably touch (>90\% intact); (2) the nestlet was partially torn up (50-90\% remaining intact); (3) the nestlet was mostly shredded without an identifiable nest site; (4) an identifiable but flat nest; and (5) a well defined nest with walls higher than the height of the mouse body.

Acoustic startle response and prepulse inhibition. Experiments were performed using the Startle Reflex System (MED Associates). Each unit consisted of a small animal holder on a movement-sensitive platform through which the movement of the mouse was transmitted and converted into a voltage signal. To measure acoustic startle response, each mouse was kept in the animal holder for 5 min with $65 \mathrm{~dB}$ background white noise for acclimation. Then 13 startle stimuli ( $20 \mathrm{~ms}$ white noise) ranging from 70 to $130 \mathrm{~dB}$ with $5 \mathrm{~dB}$ increments were delivered every $20 \mathrm{~s}$. For measurement of the prepulse inhibition (PPI), after a $5 \mathrm{~min}$ acclimation period, during which the mouse only received $65 \mathrm{~dB}$ of white background noise, the test session began with 10 trials consisting of single $40 \mathrm{~ms}, 120 \mathrm{~dB}$ white-noise startle stimuli. The sessions then continued with 56 trials, which consisted of random delivery of eight sets of $120 \mathrm{~dB}$ pulse-alone trials; a null trial, during which no stimuli were delivered; prepulse-alone trials; and prepulse trials. Prepulse trials included a single $120 \mathrm{~dB}$ pulse preceded by 20 ms nonstartling prepulse stimuli of 68,71 , 77 , and $82 \mathrm{~dB}$ for $100 \mathrm{~ms}$. The percentage of PPI was calculated as [(startle response with the prepulse - response to the middle eight $120 \mathrm{~dB}$ pulses)/ response to the middle eight $120 \mathrm{~dB}$ pulse] $\times 100$. The last 10 trials were single $40 \mathrm{~ms}, 120 \mathrm{~dB}$ pulse-alone startle stimuli. The trials were delivered with an average interval of $15 \mathrm{~s}$.

$Y$-maze spontaneous alternation. The Y-maze apparatus, made of Plexiglas, had three equally spaced arms $\left(120^{\circ}, 37 \times 7.5 \times 12.5 \mathrm{~cm}\right)$. Specific motifs were decorated on the walls of each arm, thus allowing visual discrimination, although extramaze cues of the room were also visible from the maze. Each mouse was placed at the end of one arm and allowed to freely explore the apparatus for $5 \mathrm{~min}$. The arms were labeled $\mathrm{A}, \mathrm{B}$, or C, and the sequence of arm entries was manually recorded. Entry into an arm was defined as the body and the tail of the mouse being completely within the arm. Spontaneous alternation was defined as successive entries into each of the three arms on an overlapping triplet set (e.g., $\mathrm{ABC}, \mathrm{BCA}, \mathrm{CAB})$. The percentage of spontaneous alternation performance (SAP) was defined as the ratio of actual alternation (total alternations) to possible alternations (total arm entries -2$) \times 100$.

Forced swim test. The forced swim test was performed in a transparent Plexiglas cylinder $(10 \mathrm{~cm}$ in diameter $\times 15 \mathrm{~cm}$ in height) filled with water $\left(22 \pm 2^{\circ} \mathrm{C}\right)$ to a $10 \mathrm{~cm}$ depth. Once the mouse was place into the cylinder, behavior over a 6 min period was recorded with a Noldus EthoVision XT video behavior recognition system. The duration of immobility for the last 4 min of the test session was measured to evaluate depression-like behavior.

Sucrose consumption test. Individually housed mice were used for the test. No previous food or water deprivation was applied before the test. To reduce a possible stress response to novelty, mice were presented with two water bottles containing water or $2 \%$ sucrose solution for $3 \mathrm{~h}$ before the start of the test. Five hours later, mice were given a free choice between two bottles, one with water and another with $2 \%$ sucrose. The placement of the bottles on the left or right sides was determined randomly, and bottle locations were switched at $12 \mathrm{~h}$ intervals to prevent the possible effects of a side preference in drinking behavior. The consumption of the water and sucrose solution was measured daily during a $4 \mathrm{~d}$ period. The preference for sucrose was calculated as the percentage of the sucrose solution consumed of the total amount of liquid drunk, as follows: sucrose preference $=\left[\mathrm{V}_{\text {(sucrose solution) }} /\left(\mathrm{V}_{\text {(sucrose solution) }}+\mathrm{V}_{\text {(water) }}\right] \times\right.$ $100 \%$, where $\mathrm{V}$ is volume.

Delay-cued and contextual fear conditioning. The fear-conditioning chamber is a soundproof box equipped with a speaker for delivering tones, a ventilation fan for providing air circulation and white noise, a house light, and a removable stainless steel grid floor for equally distributed delivery of a mild foot shock, controlled by Freezeframe software (Coulbourn Instruments). During training, each mouse was placed into a conditioning chamber and kept in the chamber for $2 \mathrm{~min}$ (habituation period). A tone (auditory cue, $80 \mathrm{~dB}$ ) was then presented for $30 \mathrm{~s}$, the last $2 \mathrm{~s}$ of which coincided with a single foot shock $(0.7 \mathrm{~mA})$. Each mouse received three tone and shock pairing trials with an intertrial interval of $90 \mathrm{~s}$. Animals were removed from the chamber $120 \mathrm{~s}$ after receiving the last shock. The contextual fear-conditioning test was performed $24 \mathrm{~h}$ after training in the same chamber, and freezing was scored for 5 min. Cued conditioning was conducted $48 \mathrm{~h}$ after training. Contextual cues were altered in multiple ways, such as covering the grid floor and walls with rough black plastic sheets, inserting a piece of black plastic sheet bent to form a vaulted wall, using near-infrared light instead of white light, and changing the olfactory cue. The session consisted of a 3 min period of free exploration followed by a $3 \mathrm{~min}$ period of the identical auditory conditioning stimulus $(80 \mathrm{~dB})$. Freezing was scored during both 3 min segments.

Drug administration. Clozapine was obtained from Sigma-Aldrich and dissolved in $0.1 \mathrm{~N} \mathrm{HCl}$ in physiological saline solution. The acidity was adjusted to $\mathrm{pH} 5.5$ by adding $\mathrm{NaOH}$ solution. An equivalent concentration of saline and $\mathrm{HCl}$ mixture, $\mathrm{pH} 5.5$, served as vehicle control. Clozapine $(3 \mathrm{mg} / \mathrm{kg})$ was administered by intraperitoneal injection in a volume of $6 \mathrm{ml} / \mathrm{kg} 30 \mathrm{~min}$ before the commencement of the behavioral tests. LY379268 $(3 \mathrm{mg} / \mathrm{kg})$ was dissolved in sterile saline solution and admin- 
A

AMM403-myc-S-SCAM $13.8 \mathrm{~kb}$

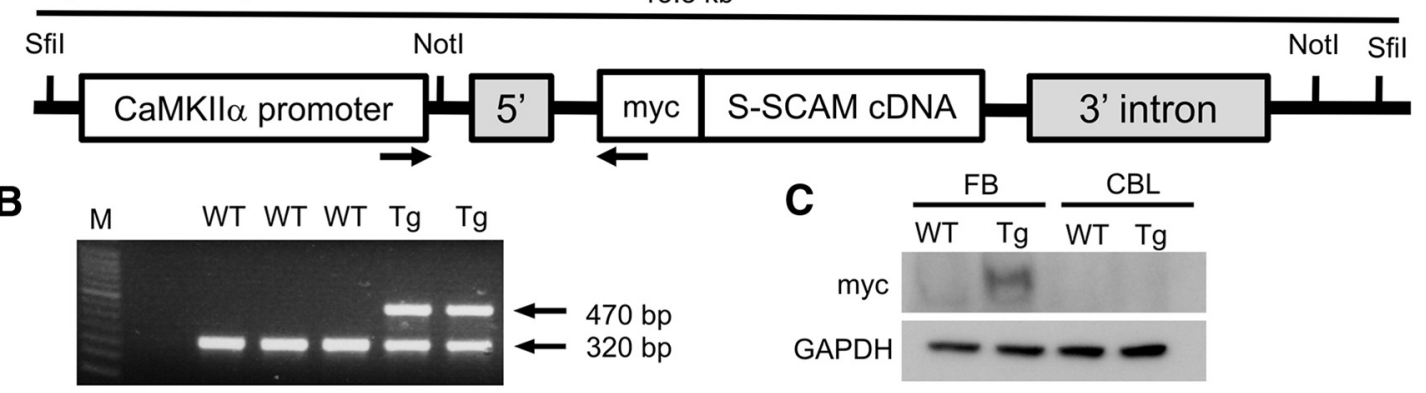

D

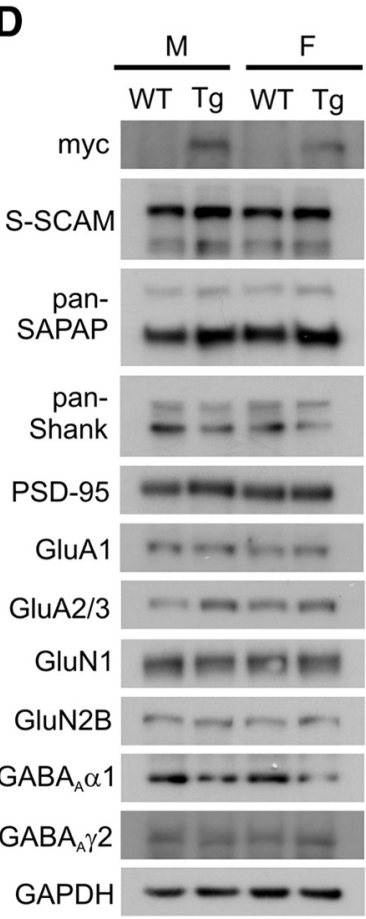
E S-SCAM
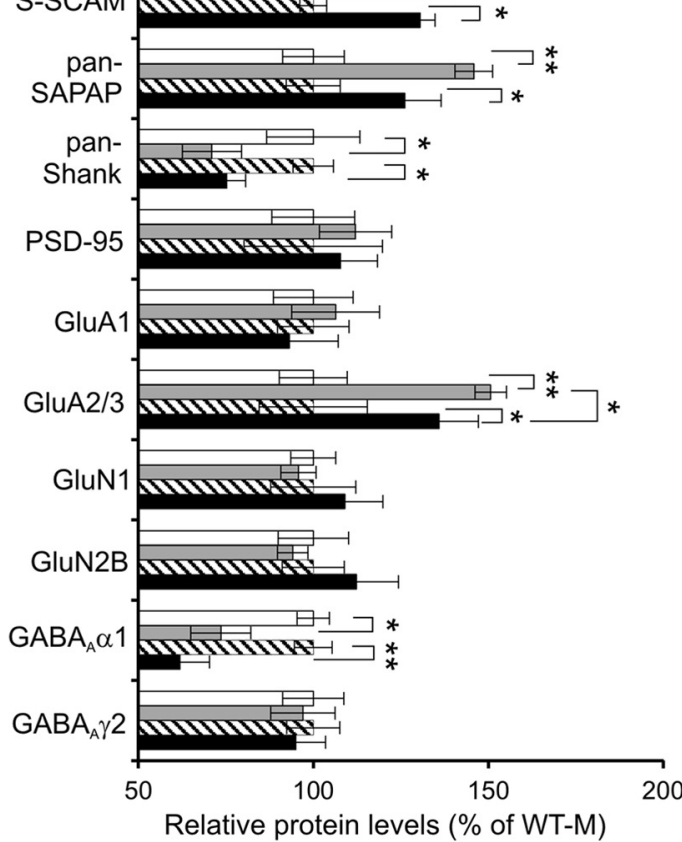

$\mathbf{F}$

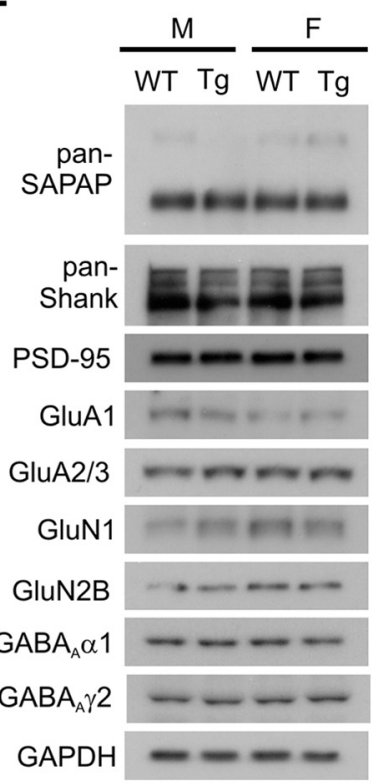

Figure 1. Generation of S-SCAM Tg mice and changes in synaptosomal protein levels. $\boldsymbol{A}$, Schematic representation of the S-SCAM transgene construct. Myc-tagged S-SCAM cDNA was placed under the control of a CaMKII- $\alpha$ promoter. Arrows indicate the positions of PCR primers used for genotyping. $\boldsymbol{B}, \mathrm{PCR}$ genotyping of S-SCAM Tg mice using the transgene specific primer set indicated in $\boldsymbol{A}$, and control primer set for mouse interleukin-2 precursor. $\boldsymbol{C}$, Forebrain-specific expression of S-SCAM transgene, determined by Western blot analyses of total protein extracted from forebrain (FB) and cerebellum (CBL) of WT and Tg animals. D, Western blot analysis of various synaptic proteins in the synaptosomal fractions prepared from the forebrain of 4-month-old WT siblings and S-SCAM Tg mice. M, Male; F, female. $E$, Quantitative analyses of the Western blot data, normalized to WT mice, are presented as the mean \pm SEM. WT-M, Tg-M, WT-F, and Tg-F mice. $n=4-6$ per group, ${ }^{*} p<0.05,{ }^{* *} p<0.01, t$ test. $\boldsymbol{F}$, Western blot analysis of various synaptic proteins in the total homogenate of the forebrain of 4-month-old WT siblings and S-SCAM Tg mice.

istered by intraperitoneal injection in a volume of $4 \mathrm{ml} / \mathrm{kg}$ once per day for $5 \mathrm{~d}$ before the behavioral tests.

\section{Results}

Generation of S-SCAM Tg mice

To mimic the conditions of S-SCAM gene duplication, we generated Tg mice carrying extra copies of S-SCAM cDNA. We used a CaMKII $\alpha$ promoter to drive transgene expression in the excitatory neurons of the forebrains from postnatal stages to the adult stage (Fig. 1A; Tsien et al., 1996). Genotyping of founders and their progenies were performed by PCR using a specific set of primers designed to detect transgene integration, as exemplified in Figure 1B. A specific 470 bp PCR product was detected only in genomic DNA samples prepared from the tails of Tg mice but not from the WT mice, indicating the integration of the transgene in the genome. Western blotting of synaptosomal fractions (P2) of brain tissue extracts using anti-myc antibody confirmed the forebrain-specific expression of the transgene, as myc-S-SCAM was undetectable in the cerebellum (Fig. 1C). The S-SCAM Tg mice showed increased levels of S-SCAM protein expression $(\sim 1.5$-fold $)$ compared with WT mice, as determined by S-SCAM-specific antibody (Fig. $1 D, E$ ).

\section{Altered synaptic protein compositions in S-SCAM Tg mouse brains}

Via its scaffolding function, S-SCAM can influence the protein compositions of synapses (Danielson et al., 2012). We therefore examined the effect of S-SCAM overexpression on the synaptic protein composition in vivo by Western blotting of synaptosomal fractions (biochemically isolated synaptic termini) prepared from the forebrains of Tg mice (Huttner et al., 1983; Lee et al., 2001). Compared with WT animals, both male (Tg-M) and female $\mathrm{Tg}(\mathrm{Tg}-\mathrm{F})$ mice showed marked increases in the synaptosomal protein levels of GluA2/3 subunits of AMPA receptors without changes in the amounts of the GluA1 and NMDA receptor subunits, GluN1 and GluNB2 (Fig. 1D,E). These are consis- 
A

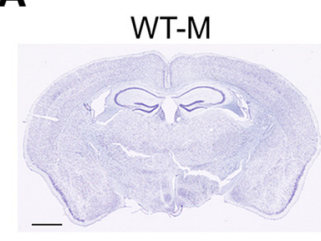

B
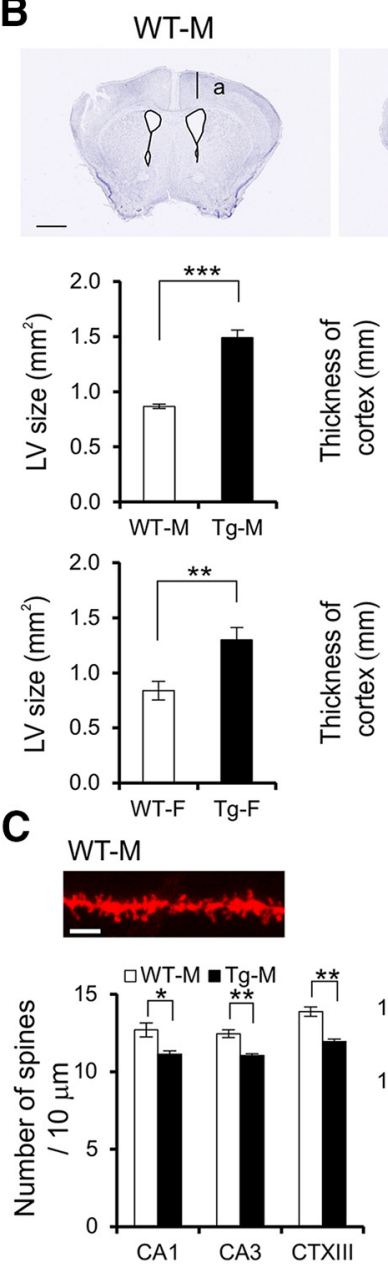

$\operatorname{Tg}-\mathrm{M}$

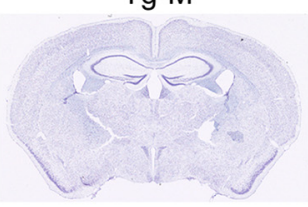

$\operatorname{Tg}-\mathrm{M}$
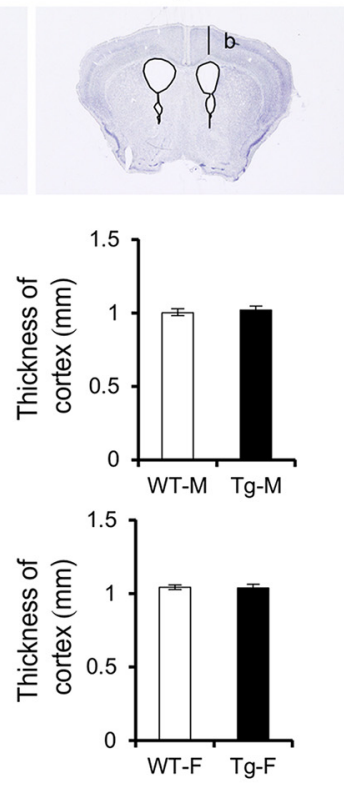

$\operatorname{Tg}-\mathrm{M}$

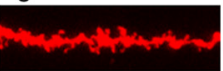

$\square W T-F \mathbf{m} T$-F

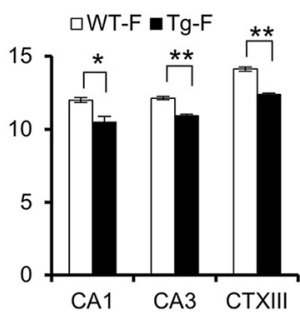

D
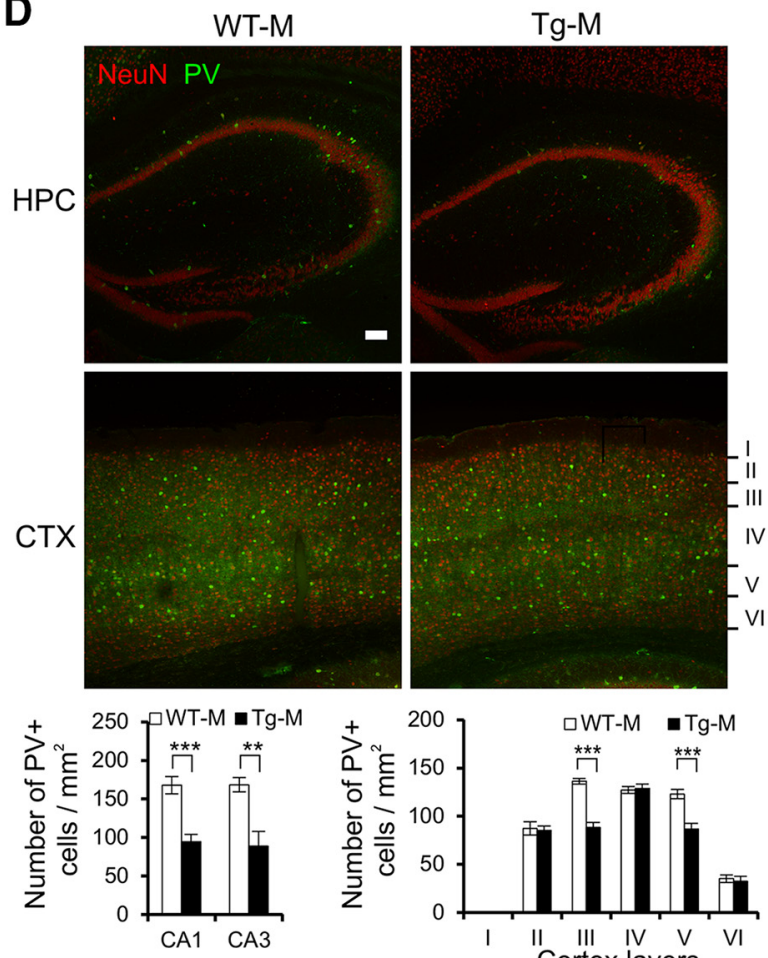

口WT-M $\quad$ Tg-M
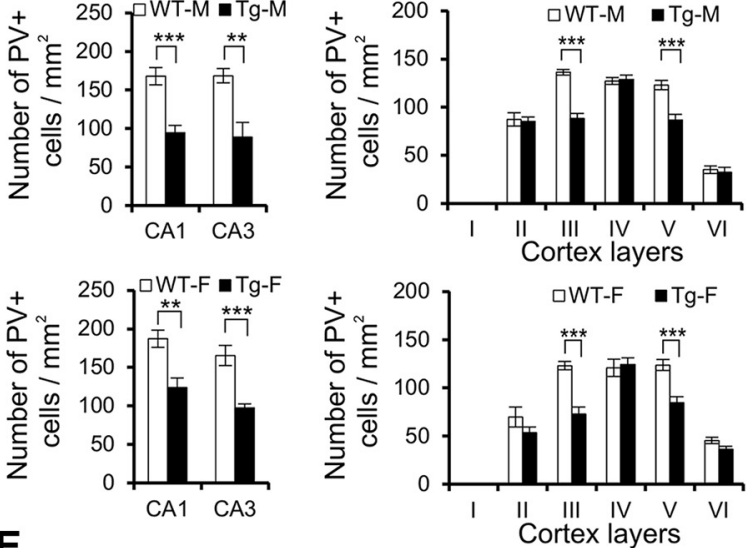

E
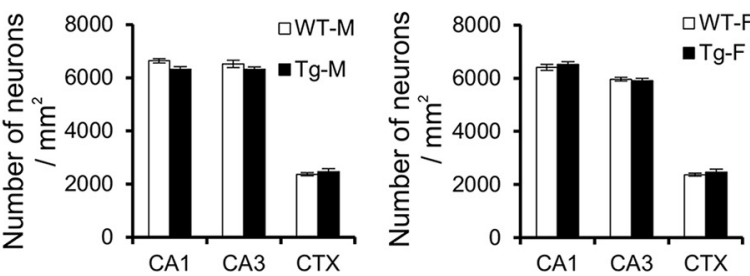

Figure 2. S-SCAM Tg mice show morphological and physiological endophenotypes associated with SZ. A, Cresyl violet staining of coronal sections of WT-M and Tg-M mice. Scale bar, 1 mm. $\boldsymbol{B}$, Enlarged LVs and normal cortical thickness in male Tg mice (top). Analysis of the LV size (left) and quantification of the thickness of cerebral cortex (right) were shown in the bottom. $n=7$ and $n=$ 4 for each male and female group, respectively. ${ }^{* * *} p<0.001, t$ test. Line a and b denote the measurement for the thickness of cerebral cortex. Scale bar, $1 \mathrm{~mm}$. C, Spine morphology of CA1 hippocampal neuron apical dendrites in WT and Tg mice, visualized by Dil staining. Scale bar, $5 \mu \mathrm{m}$. The quantification of spine densities of neurons in the CA1 and CA3 of hippocampus and somatosensory cortex layer III (CTXIII) of WT and Tg mice is shown in the right panel. $n=5-6$ per genotype. ${ }^{*} p<0.05,{ }^{* *} p<00.01, t$ test. $\boldsymbol{D}$, Immunostaining of PV in WT-M and Tg-M mouse brains (red, anti-NeuN; green, anti-PV). Scale bar, $100 \mu \mathrm{m}$. Quantification of the density of PV-stained neurons in stratum pyramidale layer of CA1 and CA3 of the hippocampal formation (HPC) (left) and various layers in somatosensory cortex (right) is shown below. $n=6$ per group. ${ }^{* *} p<0.01,{ }^{* * *} p<0.001, t$ test. $E$, Normal numbers of total neuronal cells in the CA1 and CA3 areas of hippocampus and somatosensory cortex of WT and Tg mice, measured by counting the number of NeuN + cells. $n=6$ per group. All data were presented as the mean \pm SEM.

tent with GluA2-specific scaffolding function of S-SCAM (Danielson et al., 2012). S-SCAM Tg mice also showed a large increase in SAPAPs and a significant decrease in Shank levels (Fig. $1 D, E ; p<0.05$ ), which are also consistent with our previous findings from cultured hippocampal neurons (Danielson et al., 2012). Notably, S-SCAM Tg mice showed a specific reduction in the $\alpha 1$ subunit but not in the $\gamma 2$ subunit of $\mathrm{GABA}_{\mathrm{A}}$ receptors $\left(\mathrm{GABA}_{\mathrm{A}} \mathrm{Rs}\right)$, an effect also reported in human $\mathrm{SZ}$ (Glausier and Lewis, 2011). Both male and female Tg mice showed similar qualitative changes of synaptic protein profiles, but male $\mathrm{Tg}$ mice showed a significantly larger increase in GluA2/3 levels $(p<$ $0.05)$. Importantly, the total levels of all examined proteins were not significantly altered in S-SCAM Tg forebrains (Fig. 1F). Therefore, these changes in synaptosomal protein compositions in Tg mice are highly likely due to altered accumulation and/or removal of these proteins at synapses, rather than reflecting their overall expression levels. In summary, S-SCAM overexpression in vivo altered the composition of synaptic scaffolding proteins and, most importantly, increased synaptosomal AMPA receptor levels.

\section{SZ-related morphological and cellular abnormalities in S-SCAM Tg mice}

WT and S-SCAM Tg mice were indistinguishable by their body weights and overall external appearance. Anatomical examina- 
A
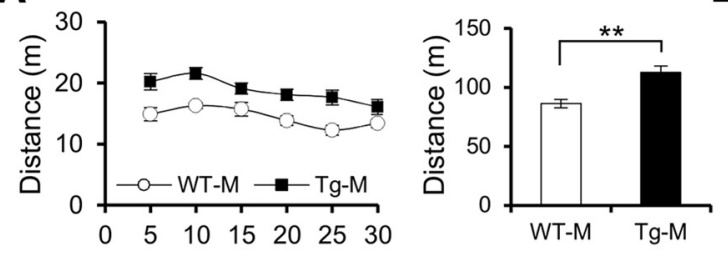

C

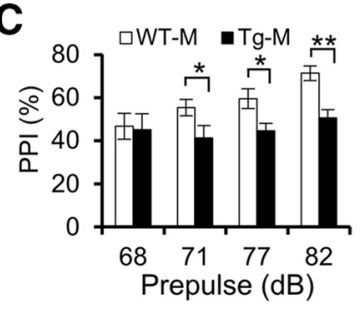

E
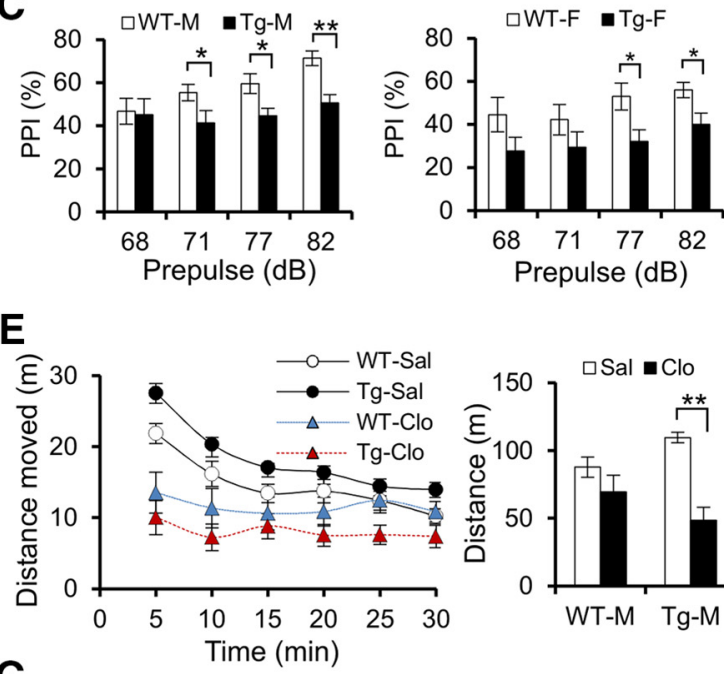

G

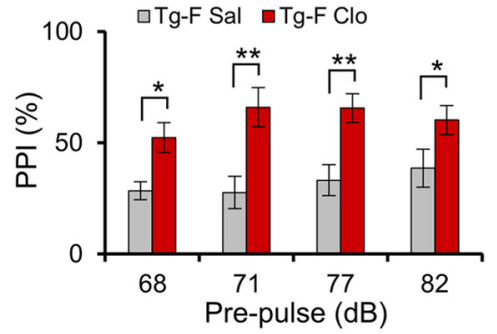

B

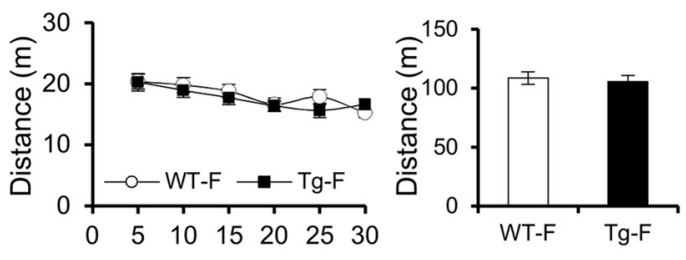

D

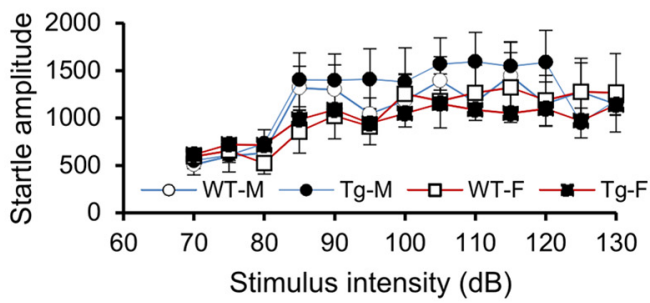

F

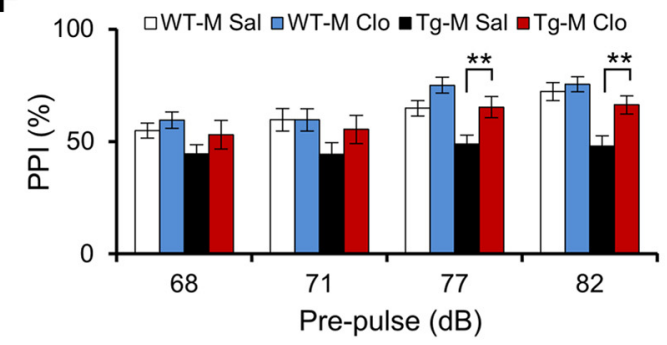

Figure 3. S-SCAM Tg mice exhibit SZ-related positive-like behavioral symptoms. $A$, Locomotor hyperactivity of Tg-M mice in the novel open field test. Total distances traveled in a 30 min session are shown. $n=10-12$ per group. ${ }^{* *} p<0.01, t$ test. $\boldsymbol{B}$, Normal locomotor activity of Tg-F mice in the novel open field test. $n=12$ per group. $\boldsymbol{C}$, Impaired PPI of the acoustic startle responses of S-SCAM Tg mice. The percentage of inhibition of the startle response was shown at four prepulse sound levels. $n=8-14$ per group. ${ }^{*} p<0.05$, ${ }^{* *} p<0.01$, two-way ANOVA. $D$, Normal acoustic startle responses of $\mathrm{Tg}$ animals, measured with startle stimuli of varying white noise intensities ( $70-130 \mathrm{~dB}) . n=8-10$ per group. $\boldsymbol{E}$, Suppressive effect of clozapine (Clo; $3 \mathrm{mg} / \mathrm{kg})$ on the hyperactivity of Tg-M mice in the open field test. Sal, Saline control. $n=9-12$ per group. ${ }^{* *} p<0.001$, two-way ANOVA. $F$, Ameliorating effect of clozapine on the PPI deficit of male Tg mice. $n=10-12$ per group. ${ }^{* *} p<0.01$, two-way ANOVA. All data were presented as the mean \pm SEM. G, Clozapine improves the PPI of female Tg mice. $n=5$ per group. ${ }^{*} p<0.05,{ }^{* *} p<0.01$, two-way ANOVA.

tion of the Tg mouse brains showed that S-SCAM Tg mice $(\sim 3$ months old) have normal layer formation and cytoarchitecture of the cerebral cortex and hippocampus (Fig. 2A,D).

Individuals with SZ frequently display common neuropathological markers, including enlargement of the LV (McCarley et al., 1999; Narr et al., 2001) and reduction in dendritic spine density (Glausier and Lewis, 2013), which were often also observed in the animal models of SZ (Hikida et al., 2007; Pletnikov et al., 2008; Barros et al., 2009). Consistent with these findings, S-SCAM Tg mice showed a significantly enlarged LV $(\sim 1.5$-fold; $p<0.01$ ), compared with WT mice (Fig. 2B). Notably, Tg-M mice showed greater alterations in the LV size than Tg-F mice $(176 \pm 8 \%$ vs $142 \pm 13 \%$, Tg-M vs Tg-F; $p<0.05)$. In contrast, the thickness of frontal cortex was normal in Tg mice (Fig. 2B). "DiOlistic" labeling of neurons (Gan et al., 2000) revealed a significant decrease in the dendritic spine densities of principal neurons in the CA1 and CA3 regions of hippocampal formation $(p<$ $0.05)$, and also in layer III of somatosensory cortices of S-SCAM Tg mice of both sexes (Fig. 2C).
PV expressing $(\mathrm{PV}+)$ neurons (basket and chandelier cells) belong to a subset of GABAergic interneurons, which are present in the cortex and the hippocampus. These interneurons play pivotal roles in the synchronized neural activity for working memory function (Lewis et al., 2005; Marín, 2012). Individuals with SZ frequently showed reduced numbers of PV + GABAergic interneurons (Benes et al., 1991; Reynolds and Beasley, 2001; Reynolds et al., 2002). S-SCAM Tg mice of both sexes showed significantly reduced numbers of PV-stained neurons in the stratum pyramidale layer of hippocampal CA1 and CA3 regions, and in layer III and layer $\mathrm{V}$ of somatosensory cortex (Fig. 2D). In contrast, the numbers of VIP + interneurons in Tg mice were not significantly different from those in WT mice [ $63 \pm 7$ vs $60 \pm 7$ per $\mathrm{mm}^{2}$, female WT (WT-F) vs Tg-F, in the CA1; $54.5 \pm 4$ per $\mathrm{mm}^{2}$ for both genotypes in the cortex; $p>0.7, t$ test]. Furthermore, S-SCAM Tg mice showed no obvious difference from WT mice in the number of total neuronal cells (determined by NeuN staining) in the hippocampal formations (CA1 and CA3 areas) and somatosensory cortex (Fig. 2E). 
A
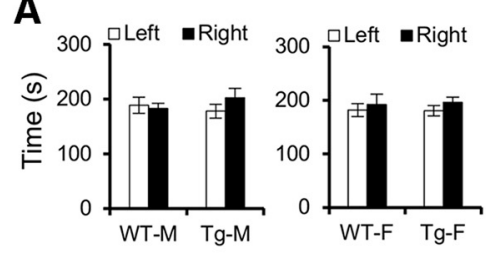

B
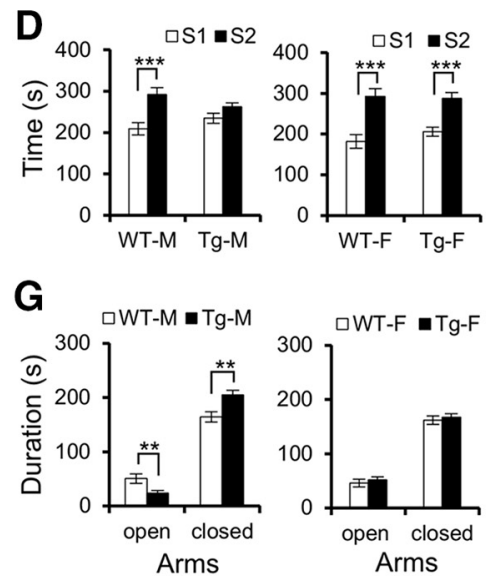

I

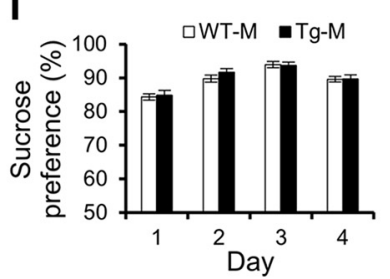

$E$

$\mathrm{H}$
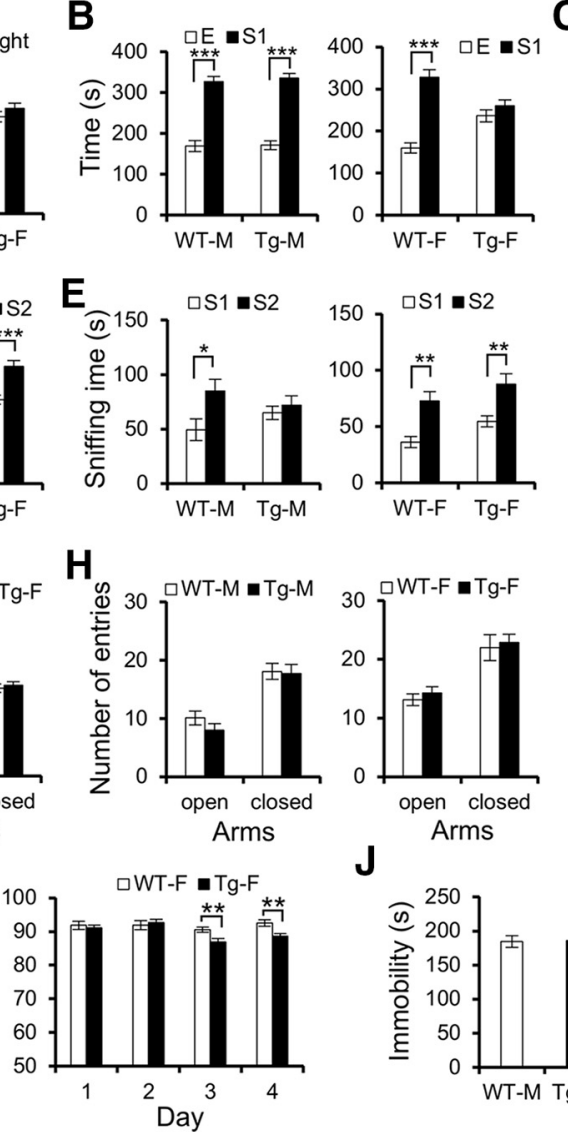

C

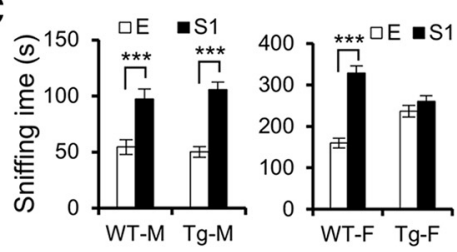

$\mathbf{F}$
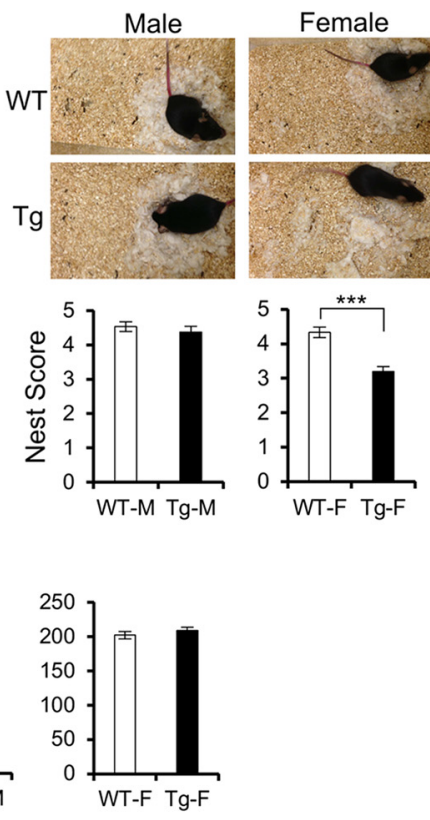

Figure 4. S-SCAM Tg mice exhibit SZ-related negative-like behavioral symptoms. A-E, Three-chamber social preference tests showing impaired sociability of Tg-F mice and impaired social novelty of Tg-M mice. $n=11-19$ per group. ${ }^{* * *} p<0.001,{ }^{* *} p<0.01,{ }^{*} p<0.05$, two-way ANOVA.A, Time spent in each empty side chamber during the initial habituation session of in the three chamber tests. $\boldsymbol{B}$, Time spent in the side chambers containing either an empty cup (E) or an $\mathrm{S1}$ mouse. C, Average sniffing time of Tg and WT mice during the sociability session of the three chamber tests. $\boldsymbol{D}$, Time spent in the side chambers containing either an $\mathrm{S} 1$ or an $\mathrm{S} 2$ mouse. $\boldsymbol{E}$, Average sniffing time of $\mathrm{Tg}$ and WT mice during the social novelty session of the three chamber tests. $\boldsymbol{F}$, Impaired nesting behavior of Tg-F mice. Representative pictures of the cages of WT and Tg mice (top), and the quality score of the nests (bottom) were shown. $n=12-15$ per group. ${ }^{* * *} p<0.001, t$ test. $\boldsymbol{G}, \boldsymbol{H}$, Anxiety-like behavior of $\mathrm{Tg}-\mathrm{M}$ mice in elevated plus maze test. Time spent in open and closed arms during a $5 \mathrm{~min}$ trial $(\boldsymbol{G})$ and number of entries to open and closed arms $(\boldsymbol{H}) . n=9-14$ per group. ${ }^{* *} p<0.01$, $t$ test. $I$, Anhedonia-like behavior of Tg-F mice in sucrose preference test. The preference for sucrose solution $(2 \%)$ over water was measured over the $4 \mathrm{~d}$ test period. ${ }^{* *} p<0.01$, $t$ test. $J$, Normal behavior of S-SCAM Tg mice in forced swim tests. Immobile time during the last 4 min of the test is shown. $n=10-13$ per group. All data were presented as the mean \pm SEM.

\section{SZ-related behavioral alterations in S-SCAM Tg mice}

Since SZ is defined by behavioral symptoms, we next examined whether S-SCAM Tg animals exhibit SZ-like behavioral endophenotypes. We used age-matched (3- to 5-month-old) littermates of WT and Tg animals for the behavioral characterization.

In open field tests, Tg-M mice traveled significantly farther than WT littermates (Fig. 3A), indicating locomotor hyperactivity in response to novelty, which models positive symptoms of SZ in rodents (Jones et al., 2011). In contrast, female Tg mice exhibited normal locomotor activity (Fig. 3B). PPI, the attenuation of startle response by a preceding nonstartling prepulse stimulus, is widely used to measure sensorimotor gating in humans and rodents, and patients with SZ show deficits in PPI (Braff and Geyer, 1990). Both male and female Tg mice showed deficits in PPI (Fig. $3 C)$. Importantly, the impaired PPI was not due to hearing loss of $\mathrm{Tg}$ mice, as they show acoustic startle responses that are similar to those in WT littermates (Fig. 3D).

Currently prescribed antipsychotic drugs attenuate the positive symptoms of SZ. Therefore, we reasoned that antipsychotic drugs may have therapeutic effects on the SZ-related positive symptoms in the S-SCAM Tg mice. To test this idea, we treated the Tg and WT male mice with clozapine, an atypical antipsychotic drug. In the open field test, clozapine treatment signifi- cantly reduced the locomotor activity of male $\mathrm{Tg}$ mice, but not WT mice (Fig. 3E). In the PPI test, clozapine treatment had no effect on the WT control mice. However, clozapine significantly restored the PPI of the Tg-M mice at prepulse levels of 77 and 82 $\mathrm{dB}$ (Fig. $3 F$ ), and improved the PPI of Tg-F mice at all prepulse levels (Fig. 3G). Thus, the SZ-related positive symptoms observed in S-SCAM Tg mice are reversible by treatment with antipsychotic drugs. These results demonstrate the pharmaceutical (predictive) validity of the S-SCAM Tg mice as an SZ animal model.

Because social withdrawal represents one of the most prominent negative symptoms in SZ patients, we evaluated social behaviors in S-SCAM Tg mice using the three-chamber test (Moy et al., 2004). In the initial habituation session, Tg mice and their WT littermates did not exhibit a side preference for the left or right chamber (Fig. 4A). During the subsequent sociability session, both WT and Tg male mice spent significantly more time and sniffed more in the chamber containing an S1 mouse than in the chamber containing an empty wire cage (Fig. $4 B, C$ ). WT-F mice also displayed a significant preference for the chamber containing the S1 mouse, whereas S-SCAM Tg female mice did not (Fig. $4 B, C$ ), indicating impaired sociability of female Tg mice. In the social novelty session, male WT (WT-M) mice showed a strong 

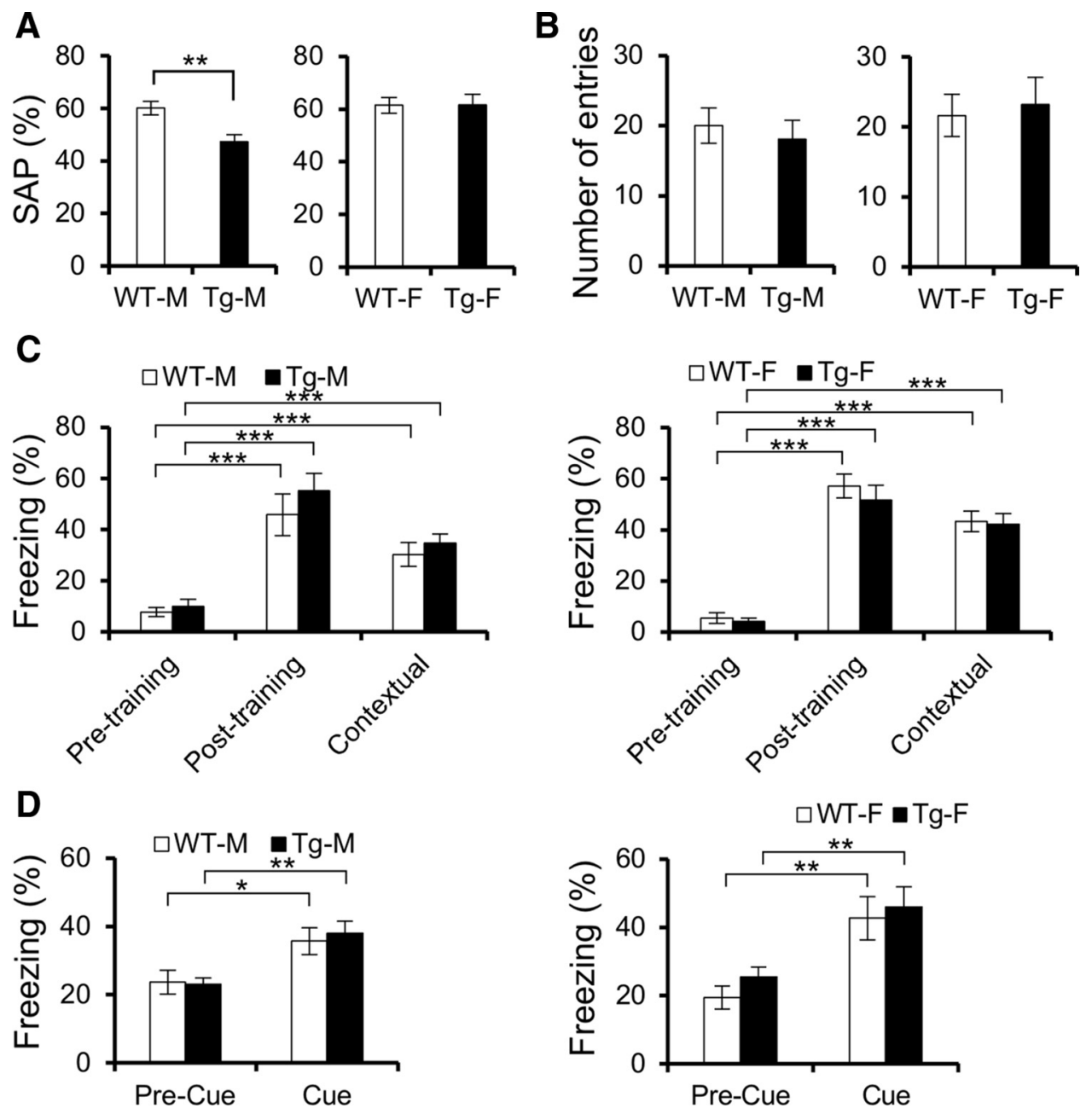

Figure 5. Deficits in the cognitive function of S-SCAM Tg mice. A, Impaired spatial working memory of Tg-M mice in Y-maze task. The percentage of correct SAPs during a 5 min trial was shown. $n=11-15$ per group. ${ }^{* *} p<0.01, t$ test. $\boldsymbol{B}$, Number of entries to each arm in the $Y$-maze test. $\boldsymbol{C}, \boldsymbol{D}$, Normal contextual and cued fear conditioning in S-SCAM Tg mice. No genotype difference was found in freezing scores in the post-training session (day 1 ), contextual conditioning (day $2 ; \boldsymbol{C}$ ), and cued response (day 3 ; $\boldsymbol{D}$ ) for both male and female mice. $n=11-13$ per group. ${ }^{*} p<0.05,{ }^{* *} p<$ $0.01,{ }^{* * *} p<0.001$, two-way ANOVA.

preference for an S2 over an S1 mouse, but Tg male mice did not have such preference for social novelty (Fig. $4 D, E$ ), suggesting deficits in social recognition and social memory. However, female Tg mice showed normal social novelty responses (Fig. $4 D, E)$. To further corroborate the abnormal social behavior of S-SCAM Tg mice, we examined nest-building behavior in the mice, which is an activity shared by all members of the home cage and thus is regarded as a behavioral measure of social interaction. Although both sexes of WT control and male Tg mice usually formed an identifiable nest in a distinct location in the cage, female $\mathrm{Tg}$ mice did not form distinguishable nests and tended to scatter pieces of nesting material over the floor (Fig. $4 F$ ). These results are consistent with the results of three-chamber tests and indicate impaired sociability of female Tg mice.

Next, we investigated whether S-SCAM Tg mice show anxiety- and depression-like behavior, which are the most common psychiatric comorbidities in patients with SZ (Tandon et al., 2009). In the elevated plus maze (EPM) test, male Tg mice spent significantly less time in the open arms and more time in the closed arms compared with WT mice (Fig. 4G), which is consistent with increased anxiety-like behavior. In contrast, female $\mathrm{Tg}$ mice spent a comparable amount of time in the open arms with WT littermates (Fig. 4G), suggesting normal anxiety levels in the female Tg mice. In the EPM tests, the total numbers of arm entries were similar between WT and Tg mice (Fig. 4H). In sucrose consumption tests, female Tg mice showed slightly reduced sucrose preference compared with female WT mice (Fig. 4I). On the other hand, in the forced swim test, S-SCAM Tg mice showed a similar immobility to that of WT littermates (Fig. $4 J$ ).

SZ patients display various forms of cognitive deficits, most prominently working memory. To study the cognitive function of Tg mice, we assessed spatial working memory using spontaneous alternation behavior in the Y-maze (Hughes, 2004). Male Tg mice displayed significantly worse spontaneous alternation performance than WT littermates (Fig. 5A). In contrast, female Tg and WT mice exhibited similar spontaneous alternation performance in the Y-maze. The number of entries into each arm was not significantly different regardless of sex and genotype among mice (Fig. 5B). These results suggest that male Tg mice, but not female Tg mice, have impaired working memory. In the contextual and cued fear-conditioning test, a paradigm to assess associative learning and reference memory (Zeng et al., 2001; Nadel and Hardt, 2011), both male and female Tg mice had normal contextual and cued fear conditioning (Fig. $5 C, D$ ). Therefore, S-SCAM Tg mice have sex (male)-specific selective (working) memory impairments. 
A

B
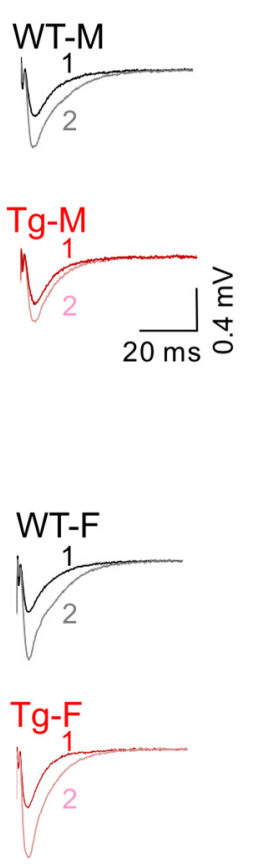

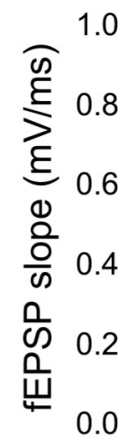

0.0
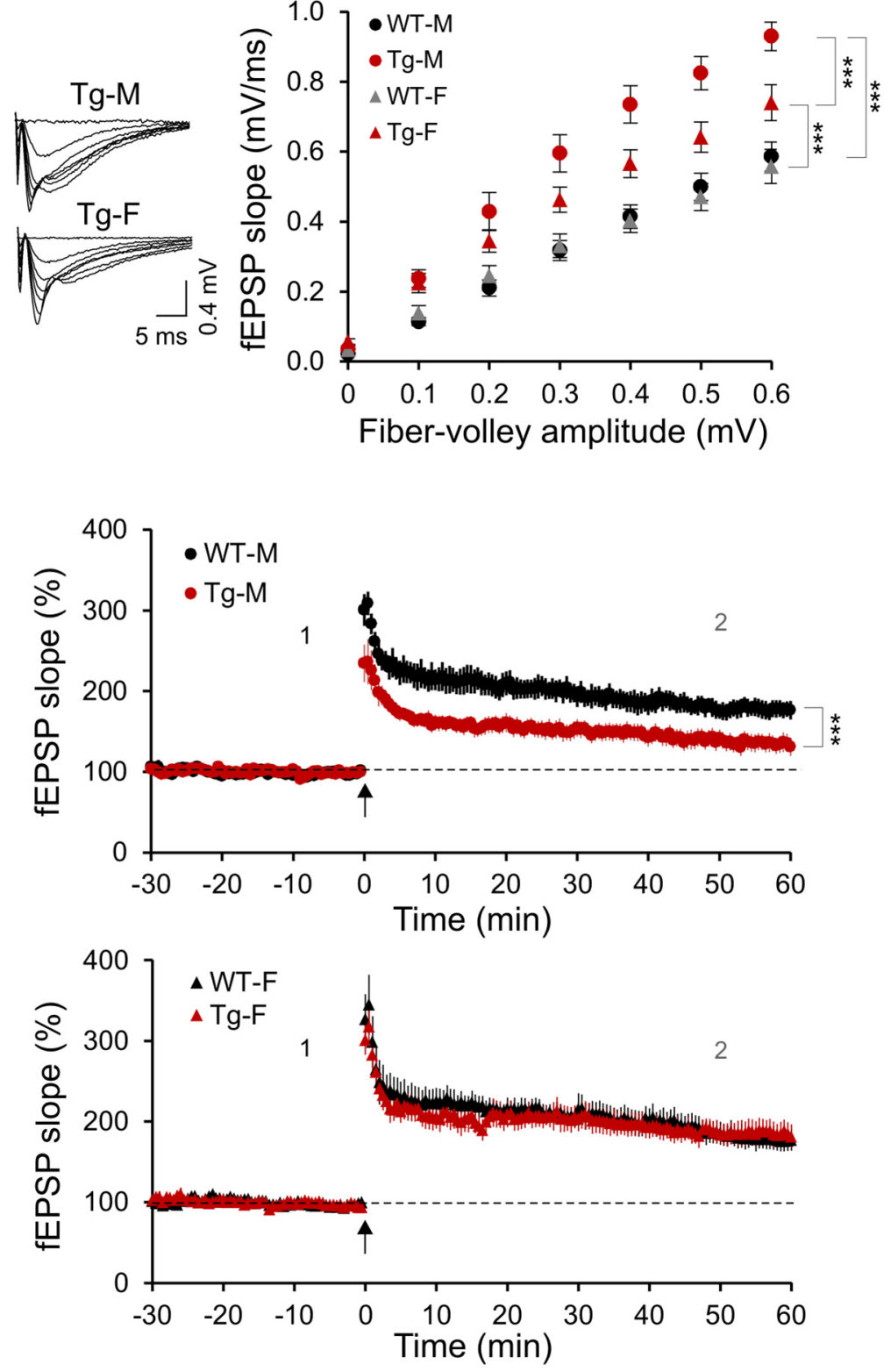

Figure 6. Sex-specific alterations of synaptic transmission and synaptic plasticity in S-SCAM Tg mice. A, Enhanced glutamatergic synaptic transmission in adult S-SCAM Tg mice (4 -5 months old). Left, Representative traces of fEPSPs at Schaffer Collateral-CA1 synapses at different stimulus intensities. Right, Summary graph of input — output relationship of WT and Tg mice. $n=9$ slices from three mice for WT-M and Tg-M mice; $n=12$ slices from four mice for WT-F mice; $n=20$ slices from seveb mice for Tg-F mice. ${ }^{* * *} p<0.001$, two-way ANOVA. $\boldsymbol{B}$, Impaired hippocampal LTP in male S-SCAM Tg mice. Sample traces of fEPSPs and summary graph of the averaged time course of LTP. Two trains of tetanic stimulation $(100 \mathrm{~Hz}, 1 \mathrm{~s} ; 20$ sinterval) were applied at the time point of 0 min. $n=8$ slices from four mice ( $4-5$ months old) for each group. ${ }^{* * *} p<0.001, t$ test. Error bars represent the SEM.

Enhanced glutamatergic synaptic transmission and sex-specific impairment of synaptic plasticity in S-SCAM Tg mice

GluA2/3 subunit levels in the synaptosomes were significantly increased in S-SCAM Tg mice (Fig. $1 D, E$ ). This suggested that elevated synaptic AMPA receptor levels and hyperglutamatergic synaptic transmission may be associated with the cognitive deficits of the mutant animals. To investigate this possibility, we examined synaptic transmission at the Schaffer Collateral-CA1 synapses. Recordings from acute hippocampal slices of young adult Tg mice (3-4 months old) showed significantly increased AMPAR-mediated fEPSPs in the stratum radiatum at all stimulation intensities tested, compared with those from age-matched WT littermates (Fig. 6A). Intriguingly, male Tg mice showed a much greater increase of fEPSPs than female Tg mice. This is consistent with the larger increase of synaptosomal GluA2/3 levels in male Tg mice than in female mice (Fig. $1 E$ ). Additionally, male Tg mice had significantly reduced hippocampal LTP induced by two trains of high-frequency stimulation $(100 \mathrm{~Hz}, 1$ min, 20 s intervals; Fig. 6B). In contrast, surprisingly, female Tg mice showed normal hippocampal LTP (Fig. 6B), despite the change (albeit smaller than male) in basal glutamatergic transmission. Thus, S-SCAM Tg mice showed male-specific impairments in hippocampal LTP.

\section{LY379268 ameliorates working memory deficits in S-SCAM}

Tg mice

To determine whether the hyperglutamatergic function is responsible for the cognitive functional deficits in S-SCAM Tg mice, we took advantage of LY379268, a specific metabotropic 

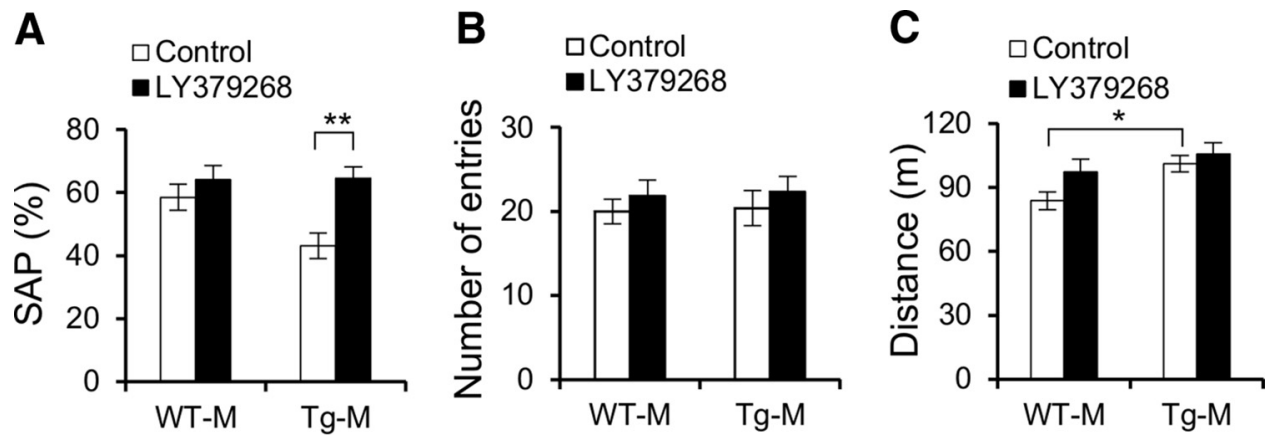

Figure 7. The effect of LY379268 on the working memory deficits of S-SCAM Tg mice. A, LY379268 improves spontaneous alteration performance of Tg-M mice in Y-maze task. The percentage of correct SAPs during a 5 min trial is shown. $n=6$ per group. ${ }^{* *} p<0.01$, two-way ANOVA. $\boldsymbol{B}$, Number of entries to each arm in the Y-maze test. C, Effect of LY379268 on the locomotor activity of WT-M and Tg-M mice in open field tests. $n=6$ per group. ${ }^{*} p<0.05$, two-way ANOVA.

Table 1. Summary of behavioral deficits in S-SCAM Tg mice

\begin{tabular}{|c|c|c|c|c|}
\hline Behavioral symptoms & Behavioral test & Modeling & Male Tg & Female $\mathrm{Tg}$ \\
\hline \multirow[t]{2}{*}{ Positive } & Open field & Psychomotor agitation & $\uparrow$ (Locomotor hyperactivity) & Normal \\
\hline & Prepulse inhibition & Sensorimotor gating & $\downarrow$ (Deficits) & $\downarrow$ (Deficits) \\
\hline \multirow[t]{5}{*}{ Negative } & Sociability (three chamber) & Social interaction & Normal & $\downarrow$ (Deficits) \\
\hline & Nest building test & Social interaction & Normal & $\downarrow$ (Deficits) \\
\hline & Elevated plus maze & Anxiety & $\uparrow$ (Increased) & Normal \\
\hline & Sucrose consumption & Anhedonia & Normal & $\downarrow$ (Reduced) \\
\hline & Spontaneous alteration (Y-maze) & Spatial working memory & $\downarrow$ (Deficits) & Normal \\
\hline \multirow[t]{2}{*}{ Cognitive } & Contextual and cued fear conditioning & Reference memory & Normal & Normal \\
\hline & Social novelty (three chamber) & Social memory/social recognition & $\downarrow$ (Deficits) & Normal \\
\hline
\end{tabular}

glutamate receptor type 2/3 (mGluR2/3) agonist (Monn et al., 1999), which reduces glutamate release at synapses through the activation of presynaptic mGluR2/3 (Lorrain et al., 2003; Schobel et al., 2013). Therefore, the administration of LY379268 is expected to reduce hyperglutamatergic activity in the S-SCAM Tg mice. Pretreatment of male WT mice with LY379268 (3 mg/kg) for $5 \mathrm{~d}$ did not affect their spontaneous alternation performance in the Y-maze (Fig. 7A). In contrast, LY379268 treatment greatly improved the spontaneous alternation performance of male $\mathrm{Tg}$ mice to a level similar to that of WT mice (Fig. $7 A$ ) without discernable changes in the number of arm entries (Fig. $7 B$ ), indicating the restoration of working memory. On the other hand, LY379268 treatment did not influence the increased locomotor activity of male Tg mice in the open field test (Fig. 7C), showing the specific effect of LY379268 on the working memory.

\section{Discussion}

In this report, we have shown that the elevation of S-SCAM expression in the excitatory neurons of forebrain was sufficient to induce an SZ-like phenotype in mice. The significance of these findings is multifold.

First, our data provide experimental evidence supporting the validity of the rare CNV hypothesis in SZ pathogenesis. Recent genome-wide studies have uncovered numerous CNVs in diverse genes (Walsh et al., 2008; Need et al., 2009; Malhotra et al., 2011; Kirov et al., 2012). However, these CNVs are often specific to single cases or families. Therefore, the intrinsic rarity of CNVs lays doubt on the causality of these mutations and smears their implication for SZ etiology. The generation and characterization of animal models simulating the mutations for an SZ-like endophenotype would provide the most compelling evidence for the validity of the rare CNV hypothesis. To our knowledge, we present the first demonstration that modeling the effects of a single rare $\mathrm{CNV}$ resulted in multiple SZ endophenotypes.
Second, S-SCAM Tg mice offer a new animal model of SZ, which displays a wide array of SZ-related endophenotypes observed in human SZ (Table 1). A limitation of most animal models of SZ is the lack of phenotypes associated with negative and cognitive symptoms of SZ (Jones et al., 2011). In contrast, S-SCAM Tg mice not only displayed all three domains of behavioral symptoms, including cognitive deficits, but also exhibited cellular/morphological deficits, consistent with the neurodevelopmental model of SZ. In addition, S-SCAM Tg mice showed unique sexual dimorphism in behavioral deficits and glutamatergic synaptic function, which are poorly characterized aspects in animal models of SZ. Sex differences in an SZ animal model have been described previously only in an inducible mutant human DISC1 Tg mouse model (Pletnikov et al., 2008). In this model, although both male and female mice have normal PPIs and anxiety levels, male mice showed hyperactivity and social deficits, and female mice showed only deficient spatial reference memory. In contrast, S-SCAM Tg males exhibit more complete SZ-related symptoms, including deficits in cognitive function (social memory and spatial working memory). Female S-SCAM Tg showed PPI deficits and impaired sociability, but normal social and spatial working memory. These are in general consistent with human conditions - men with SZ experience more severe symptoms and worse cognitive impairments. Thus, S-SCAM Tg mice offer a new SZ model for studying SZ pathobiology in manners previously impossible to approach. For example, one can directly test the “estrogen hypothesis" (Kulkarni et al., 2012), postulating a protective role of estrogen in SZ with the S-SCAM Tg model.

Third, SZ is believed to be associated with an excitation/inhibition imbalance, and the hyperactivity of excitatory neurons has been found in SZ pathogenesis models (Kehrer et al., 2008). These hyperglutamate models are associated with hypo-NMDAR function in PV+ interneurons (Marín, 2012). In contrast, 
S-SCAM Tg mouse model exhibits hyper-AMPAR function in excitatory neurons, highlighting the potential importance of AMPARs and principal neurons in SZ pathogenesis.

Considering the direct interaction of S-SCAM with ErbB4 receptors (Buxbaum et al., 2008), our results suggest the hypothesis that aberrant regulation of the signaling pathway of NRG1ErbB4-S-SCAM leads to SZ pathogenesis (Mei and Xiong, 2008). This is consistent with the findings that diverse types of SZassociated mutations converge on common signaling pathways (Gilman et al., 2012) and also with the notion that abnormalities of postsynaptic signaling complexes are involved in the pathogenesis of SZ (Kirov et al., 2012). However, the hypothesis is not directly relevant to the current S-SCAM Tg SZ model since the major expression of ErbB4 seems to be restricted to PV+ interneurons (Yau et al., 2003; Vullhorst et al., 2009; Fazzari et al., 2010). Nonetheless, endogenous S-SCAM is expressed in both excitatory and inhibitory interneurons (Sumita et al., 2007), and the regulatory action of ErbB4 on AMPA receptors has been demonstrated in principal neurons (Li et al., 2007). Furthermore, the deletion of ErbB4 in PV+ neurons decreased dendritic spines in excitatory neurons (Yin et al., 2013a), indicating the presence of a non-cell-autonomous mechanism. Therefore, further studies are required to determine the functional significance of S-SCAM in NRG-1-ErbB4 signaling in SZ pathogenesis.

What are the pathological bases of SZ endophenotypes in S-SCAM Tg mice? S-SCAM Tg mice showed greatly enhanced excitatory synaptic transmission. The elevation of synaptic strength was detrimental to the induction of normal synaptic plasticity, as male S-SCAM Tg mice showed significantly impaired LTP, suggesting an occlusion. Thus, in male S-SCAM Tg mice, it seems that S-SCAM overexpression elevated basal synaptic AMPA receptors to such a high level that a partial saturation occurred. This interpretation is consistent with our findings that S-SCAM Tg mice showed a specific increase of GluA2/3 levels in the synaptosomes, and the overexpression of S-SCAM in cultured hippocampal neurons specifically increased both AMPA receptor-mediated miniature and evoked EPSCs without altering presynaptic function (Danielson et al., 2012), indicating the involvement of a postsynaptic mechanism. Therefore, S-SCAM Tg mice represent a unique SZ model of enhanced glutamatergic function, which is due to a postsynaptic increase of AMPA receptor levels. Furthermore, these in vivo and in vitro findings suggest a role for S-SCAM in setting the basal levels of synaptic AMPA receptors and its function as a hypothetical "slot" protein for AMPA receptors (Sheng and Hyoung Lee, 2003). Importantly, despite the enhanced basal glutamatergic transmission (albeit to a lesser degree than in male $\mathrm{Tg}$ mice), female $\mathrm{Tg}$ mice showed normal LTP and no deficits in working memory. Therefore, the impaired synaptic plasticity associated with hyperglutamatergic function in male S-SCAM Tg mice likely accounts for the cognitive deficits. Directly supporting this notion, reducing glutamate release by LY379268 ameliorated the working memory deficits of male S-SCAM Tg mice. It would be important to determine whether LY379263 treatment restores LTP in the Tg-M mice. The potential therapeutic application of LY379268 is notable, since traditional antipsychotic drugs have little therapeutic benefit on cognitive deficits, although they attenuate positive symptoms.

S-SCAM Tg animals also showed pathological mechanisms related to interneuron dysfunction (Marín, 2012). They showed reduced synaptosomal $\mathrm{GABA}_{\mathrm{A}} \mathrm{R} \alpha 1$ levels, consistent with observation from patients with SZ (Glausier and Lewis, 2011) and ctoNRG1 SZ model mice (Yin et al., 2013b). The reduction in the number of PV-stained cells in S-SCAM Tg mice likely contributes to the decrease, as $\mathrm{GABA}_{\mathrm{A}} \mathrm{R} \alpha 1$ is mainly present at synapses formed by PV+ interneurons (Rudolph and Möhler, 2006). The reduction of $\mathrm{PV}+$ neurons has been frequently observed in human SZ and animal models of SZ (Marín, 2012). Considering that the S-SCAM transgene is expressed only in excitatory neurons, the reduction in PV-stained interneurons is an unexpected phenomenon. Interestingly, excess glutamate was sufficient to reduce the number of $\mathrm{PV}+$ neurons in a repeated ketamine exposure SZ model (Schobel et al., 2013). The decrease in the number of PV-stained interneurons does not necessarily mean the loss (death) of PV+ inhibitory neurons and could be also due to the reduced expression of PV mRNA in these types of interneurons (Lewis et al., 2012). Distinguishing these two possibilities would require further intensive investigation. However, we note that the loss of PV expression enhanced inhibition and increased the power of gamma oscillation in the hippocampus of PV knock-out mice (Vreugdenhil et al., 2003). Considering that reduction in the power of gamma oscillation is associated with working memory deficits in SZ (Volk and Lewis, 2014), the reduced staining of $\mathrm{PV}+$ neurons in S-SCAM Tg mice is more likely due to the loss of $\mathrm{PV}+$ neurons. Given that S-SCAM is a scaffold protein that binds directly to Axin (Hirabayashi et al., 2004), $\beta$-catenin (Nishimura et al., 2002), Smad3, and activin RIIA (Shoji et al., 2000), alternative potential possibilities include that abnormal levels of S-SCAM may influence normal development of PV + neurons by perturbing Wnt and TGF- $\beta$ signaling (Zhou et al., 2003; Paina et al., 2011).

Excitatory activity can shape GABAergic function (Flores and Méndez, 2014). For example, activity-induced expression of Npas4 not only regulates inhibitory synapse formation in excitatory neurons, but also changes gene expression programs in GABAergic neurons (Spiegel et al., 2014). Interestingly, Npas4 knock-out mice exhibited SZ-like behavioral abnormalities (Coutellier et al., 2012). Therefore, it would be interesting to study the mechanisms and the potential role of Npas4 in the functional interaction of excitatory and GABAergic pathways in S-SCAM Tg mice and other SZ animal models.

\section{References}

Abel KM, Drake R, Goldstein JM (2010) Sex differences in schizophrenia. Int Rev Psychiatry 22:417-428. CrossRef Medline

Barros CS, Calabrese B, Chamero P, Roberts AJ, Korzus E, Lloyd K, Stowers L, Mayford M, Halpain S, Müller U (2009) Impaired maturation of dendritic spines without disorganization of cortical cell layers in mice lacking NRG1/ErbB signaling in the central nervous system. Proc Natl Acad Sci U S A 106:4507-4512. CrossRef Medline

Begemann MJ, Dekker CF, van Lunenburg M, Sommer IE (2012) Estrogen augmentation in schizophrenia: a quantitative review of current evidence. Schizophr Res 141:179-184. CrossRef Medline

Benes FM, McSparren J, Bird ED, SanGiovanni JP, Vincent SL (1991) Deficits in small interneurons in prefrontal and cingulate cortices of schizophrenic and schizoaffective patients. Arch Gen Psychiatry 48:996-1001. CrossRef Medline

Braff DL, Geyer MA (1990) Sensorimotor gating and schizophrenia. Human and animal model studies. Arch Gen Psychiatry 47:181-188. CrossRef Medline

Buxbaum JD, Georgieva L, Young JJ, Plescia C, Kajiwara Y, Jiang Y, Moskvina V, Norton N, Peirce T, Williams H, Craddock NJ, Carroll L, Corfas G, Davis KL, Owen MJ, Harroch S, Sakurai T, O’Donovan MC (2008) Molecular dissection of NRG1-ERBB4 signaling implicates PTPRZ1 as a potential schizophrenia susceptibility gene. Mol Psychiatry 13:162-172. CrossRef Medline

Coutellier L, Beraki S, Ardestani PM, Saw NL, Shamloo M (2012) Npas4: a neuronal transcription factor with a key role in social and cognitive functions relevant to developmental disorders. PLoS One 7:e46604. CrossRef Medline

Danielson E, Zhang N, Metallo J, Kaleka K, Shin SM, Gerges N, Lee SH 
(2012) S-SCAM/MAGI-2 is an essential synaptic scaffolding molecule for the GluA2-containing maintenance pool of AMPA receptors. J Neurosci 32:6967-6980. CrossRef Medline

Deacon RM (2006) Assessing nest building in mice. Nat Protoc 1:1117-1119. CrossRef Medline

Fazzari P, Paternain AV, Valiente M, Pla R, Luján R, Lloyd K, Lerma J, Marín O, Rico B (2010) Control of cortical GABA circuitry development by Nrg1 and ErbB4 signalling. Nature 464:1376-1380. CrossRef Medline

Flores CE, Méndez P (2014) Shaping inhibition: activity dependent structural plasticity of GABAergic synapses. Front Cell Neurosci 8:327. CrossRef Medline

Gan WB, Grutzendler J, Wong WT, Wong RO, Lichtman JW (2000) Multicolor "DiOlistic" labeling of the nervous system using lipophilic dye combinations. Neuron 27:219-225. CrossRef Medline

Gilman SR, Chang J, Xu B, Bawa TS, Gogos JA, Karayiorgou M, Vitkup D (2012) Diverse types of genetic variation converge on functional gene networks involved in schizophrenia. Nat Neurosci 15:1723-1728. CrossRef Medline

Glausier JR, Lewis DA (2011) Selective pyramidal cell reduction of GABA(A) receptor alpha1 subunit messenger RNA expression in schizophrenia. Neuropsychopharmacology 36:2103-2110. CrossRef Medline

Glausier JR, Lewis DA (2013) Dendritic spine pathology in schizophrenia. Neuroscience 251:90-107. CrossRef Medline

Hikida T, Jaaro-Peled H, Seshadri S, Oishi K, Hookway C, Kong S, Wu D, Xue R, Andradé M, Tankou S, Mori S, Gallagher M, Ishizuka K, Pletnikov M, Kida S, Sawa A (2007) Dominant-negative DISC1 transgenic mice display schizophrenia-associated phenotypes detected by measures translatable to humans. Proc Natl Acad Sci U S A 104:14501-14506. CrossRef Medline

Hirabayashi S, Nishimura W, Iida J, Kansaku A, Kishida S, Kikuchi A, Tanaka N, Hata Y (2004) Synaptic scaffolding molecule interacts with axin. J Neurochem 90:332-339. CrossRef Medline

Hirao K, Hata Y, Ide N, Takeuchi M, Irie M, Yao I, Deguchi M, Toyoda A, Sudhof TC, Takai Y (1998) A novel multiple PDZ domain-containing molecule interacting with $\mathrm{N}$-methyl-D-aspartate receptors and neuronal cell adhesion proteins. J Biol Chem 273:21105-21110. CrossRef Medline

Hughes RN (2004) The value of spontaneous alternation behavior (SAB) as a test of retention in pharmacological investigations of memory. Neurosci Biobehav Rev 28:497-505. CrossRef Medline

Huttner WB, Schiebler W, Greengard P, De Camilli P (1983) Synapsin I (protein I), a nerve terminal-specific phosphoprotein. III. Its association with synaptic vesicles studied in a highly purified synaptic vesicle preparation. J Cell Biol 96:1374-1388. CrossRef Medline

Jones CA, Watson DJ, Fone KC (2011) Animal models of schizophrenia. Br J Pharmacol 164:1162-1194. CrossRef Medline

Karlsson R, Graae L, Lekman M, Wang D, Favis R, Axelsson T, Galter D, Belin AC, Paddock S (2012) MAGI1 copy number variation in bipolar affective disorder and schizophrenia. Biol Psychiatry 71:922-930. CrossRef Medline

Kehrer C, Maziashvili N, Dugladze T, Gloveli T (2008) Altered excitatoryinhibitory balance in the NMDA-hypofunction model of schizophrenia. Front Mol Neurosci 1:6. CrossRef Medline

Kirov G, Pocklington AJ, Holmans P, Ivanov D, Ikeda M, Ruderfer D, Moran J, Chambert K, Toncheva D, Georgieva L, Grozeva D, Fjodorova M, Wollerton R, Rees E, Nikolov I, van de Lagemaat LN, Bayés A, Fernandez E, Olason PI, Böttcher Y, et al. (2012) De novo CNV analysis implicates specific abnormalities of postsynaptic signalling complexes in the pathogenesis of schizophrenia. Mol Psychiatry 17:142-153. CrossRef Medline

Koide T, Banno M, Aleksic B, Yamashita S, Kikuchi T, Kohmura K, Adachi Y, Kawano N, Kushima I, Nakamura Y, Okada T, Ikeda M, Ohi K, Yasuda Y, Hashimoto R, Inada T, Ujike $\mathrm{H}$, Iidaka T, Suzuki M, Takeda M, et al (2012) Common variants in MAGI2 gene are associated with increased risk for cognitive impairment in schizophrenic patients. PLoS One 7:e36836. CrossRef Medline

Kulkarni J, Hayes E, Gavrilidis E (2012) Hormones and schizophrenia. Curr Opin Psychiatry 25:89-95. CrossRef Medline

Lee SH, Valtschanoff JG, Kharazia VN, Weinberg R, Sheng M (2001) Biochemical and morphological characterization of an intracellular membrane compartment containing AMPA receptors. Neuropharmacology 41:680-692. CrossRef Medline

Lewis DA, Hashimoto T, Volk DW (2005) Cortical inhibitory neurons and schizophrenia. Nat Rev Neurosci 6:312-324. CrossRef Medline

Lewis DA, Curley AA, Glausier JR, Volk DW (2012) Cortical parvalbumin interneurons and cognitive dysfunction in schizophrenia. Trends Neurosci 35:57-67. CrossRef Medline

Li B, Woo RS, Mei L, Malinow R (2007) The neuregulin-1 receptor erbB4 controls glutamatergic synapse maturation and plasticity. Neuron 54: 583-597. CrossRef Medline

Lorrain DS, Baccei CS, Bristow LJ, Anderson JJ, Varney MA (2003) Effects of ketamine and N-methyl-D-aspartate on glutamate and dopamine release in the rat prefrontal cortex: modulation by a group II selective metabotropic glutamate receptor agonist LY379268. Neuroscience 117: 697-706. CrossRef Medline

Malhotra D, McCarthy S, Michaelson JJ, Vacic V, Burdick KE, Yoon S, Cichon S, Corvin A, Gary S, Gershon ES, Gill M, Karayiorgou M, Kelsoe JR, Krastoshevsky O, Krause V, Leibenluft E, Levy DL, Makarov V, Bhandari A, Malhotra AK, et al. (2011) High frequencies of de novo CNVs in bipolar disorder and schizophrenia. Neuron 72:951-963. CrossRef Medline

Marín O (2012) Interneuron dysfunction in psychiatric disorders. Nat Rev Neurosci 13:107-120. CrossRef Medline

McCarley RW, Wible CG, Frumin M, Hirayasu Y, Levitt JJ, Fischer IA, Shenton ME (1999) MRI anatomy of schizophrenia. Biol Psychiatry 45: 1099-1119. CrossRef Medline

Mei L, Xiong WC (2008) Neuregulin 1 in neural development, synaptic plasticity and schizophrenia. Nat Rev Neurosci 9:437-452. CrossRef Medline

Millar JK, Wilson-Annan JC, Anderson S, Christie S, Taylor MS, Semple CA, Devon RS, St Clair DM, Muir WJ, Blackwood DH, Porteous DJ (2000) Disruption of two novel genes by a translocation cosegregating with schizophrenia. Hum Mol Genet 9:1415-1423. CrossRef Medline

Monn JA, Valli MJ, Massey SM, Hansen MM, Kress TJ, Wepsiec JP, Harkness AR, Grutsch JL Jr, Wright RA, Johnson BG, Andis SL, Kingston A, Tomlinson R, Lewis R, Griffey KR, Tizzano JP, Schoepp DD (1999) Synthesis, pharmacological characterization, and molecular modeling of heterobicyclic amino acids related to (+)-2-aminobicyclo[3.1.0] hexane-2,6-dicarboxylic acid (LY354740): identification of two new potent, selective, and systemically active agonists for group II metabotropic glutamate receptors. J Med Chem 42:1027-1040. CrossRef Medline

Mowry BJ, Gratten J (2013) The emerging spectrum of allelic variation in schizophrenia: current evidence and strategies for the identification and functional characterization of common and rare variants. Mol Psychiatry 18:38-52. CrossRef Medline

Moy SS, Nadler JJ, Perez A, Barbaro RP, Johns JM, Magnuson TR, Piven J, Crawley JN (2004) Sociability and preference for social novelty in five inbred strains: an approach to assess autistic-like behavior in mice. Genes Brain Behav 3:287-302. CrossRef Medline

Nadel L, Hardt O (2011) Update on memory systems and processes. Neuropsychopharmacology 36:251-273. CrossRef Medline

Narr KL, Thompson PM, Sharma T, Moussai J, Blanton R, Anvar B, Edris A, Krupp R, Rayman J, Khaledy M, Toga AW (2001) Three-dimensional mapping of temporo-limbic regions and the lateral ventricles in schizophrenia: gender effects. Biol Psychiatry 50:84-97. CrossRef Medline

Need AC, Ge D, Weale ME, Maia J, Feng S, Heinzen EL, Shianna KV, Yoon W, Kasperaviciūte D, Gennarelli M, Strittmatter WJ, Bonvicini C, Rossi G, Jayathilake K, Cola PA, McEvoy JP, Keefe RS, Fisher EM, St Jean PL, Giegling I, et al. (2009) A genome-wide investigation of SNPs and CNVs in schizophrenia. PLoS Genet 5:e1000373. CrossRef Medline

Nishimura W, Yao I, Iida J, Tanaka N, Hata Y (2002) Interaction of synaptic scaffolding molecule and $\beta$-catenin. J Neurosci 22:757-765. Medline

Nuechterlein KH, Barch DM, Gold JM, Goldberg TE, Green MF, Heaton RK (2004) Identification of separable cognitive factors in schizophrenia. Schizophr Res 72:29-39. CrossRef Medline

Paina S, Garzotto D, DeMarchis S, Marino M, Moiana A, Conti L, Cattaneo E, Perera M, Corte G, Calautti E, Merlo GR (2011) Wnt5a is a transcriptional target of $D l x$ homeogenes and promotes differentiation of interneuron progenitors in vitro and in vivo. J Neurosci 31:2675-2687. CrossRef Medline

Pan B, Wang W, Long JZ, Sun D, Hillard CJ, Cravatt BF, Liu QS (2009) Blockade of 2-arachidonoylglycerol hydrolysis by selective monoacylglycerol lipase inhibitor 4-nitrophenyl 4-(dibenzo[d] [1,3] dioxol-5-yl(hydroxy)methyl)piperidine-1carboxylate (JZL184) Enhances retrograde endocannabinoid signaling. J Pharmacol Exp Ther 331:591-597. CrossRef Medline

Pearlson GD (2000) Neurobiology of schizophrenia. Ann Neurol 48:556566. Medline

Pletnikov MV, Ayhan Y, Nikolskaia O, Xu Y, Ovanesov MV, Huang H, Mori 
S, Moran TH, Ross CA (2008) Inducible expression of mutant human DISC1 in mice is associated with brain and behavioral abnormalities reminiscent of schizophrenia. Mol Psychiatry 13:173-186. CrossRef Medline

Reynolds GP, Beasley CL (2001) GABAergic neuronal subtypes in the human frontal cortex-development and deficits in schizophrenia. J Chem Neuroanat 22:95-100. CrossRef Medline

Reynolds GP, Beasley CL, Zhang ZJ (2002) Understanding the neurotransmitter pathology of schizophrenia: selective deficits of subtypes of cortical GABAergic neurons. J Neural Transm 109:881-889. CrossRef Medline

Rudolph U, Möhler H (2006) GABA-based therapeutic approaches: GABAA receptor subtype functions. Curr Opin Pharmacol 6:18-23. CrossRef Medline

Schobel SA, Chaudhury NH, Khan UA, Paniagua B, Styner MA, Asllani I, Inbar BP, Corcoran CM, Lieberman JA, Moore H, Small SA (2013) Imaging patients with psychosis and a mouse model establishes a spreading pattern of hippocampal dysfunction and implicates glutamate as a driver. Neuron 78:81-93. CrossRef Medline

Sheng M, Hyoung Lee S (2003) AMPA receptor trafficking and synaptic plasticity: major unanswered questions. Neurosci Res 46:127-134. CrossRef Medline

Shoji H, Tsuchida K, Kishi H, Yamakawa N, Matsuzaki T, Liu Z, Nakamura T, Sugino H (2000) Identification and characterization of a PDZ protein that interacts with activin type II receptors. J Biol Chem 275:5485-5492. CrossRef Medline

Spiegel I, Mardinly AR, Gabel HW, Bazinet JE, Couch CH, Tzeng CP, Harmin DA, Greenberg ME (2014) Npas4 regulates excitatory-inhibitory balance within neural circuits through cell-type-specific gene programs. Cell 157:1216-1229. CrossRef Medline

Stan A, Pielarski KN, Brigadski T, Wittenmayer N, Fedorchenko O, Gohla A, Lessmann V, Dresbach T, Gottmann K (2010) Essential cooperation of $\mathrm{N}$-cadherin and neuroligin-1 in the transsynaptic control of vesicle accumulation. Proc Natl Acad Sci U S A 107:11116-11121. CrossRef Medline

Stefansson H, Sigurdsson E, Steinthorsdottir V, Bjornsdottir S, Sigmundsson T, Ghosh S, Brynjolfsson J, Gunnarsdottir S, Ivarsson O, Chou TT, Hjaltason O, Birgisdottir B, Jonsson H, Gudnadottir VG, Gudmundsdottir E, Bjornsson A, Ingvarsson B, Ingason A, Sigfusson S, Hardardottir H, et al (2002) Neuregulin 1 and susceptibility to schizophrenia. Am J Hum Genet 71:877-892. CrossRef Medline

Sumita K, Sato Y, Iida J, Kawata A, Hamano M, Hirabayashi S, Ohno K, Peles E, Hata Y (2007) Synaptic scaffolding molecule (S-SCAM) membraneassociated guanylate kinase with inverted organization (MAGI)-2 is associated with cell adhesion molecules at inhibitory synapses in rat hippocampal neurons. J Neurochem 100:154-166. CrossRef Medline

Sun C, Cheng MC, Qin R, Liao DL, Chen TT, Koong FJ, Chen G, Chen CH (2011) Identification and functional characterization of rare mutations of the neuroligin-2 gene (NLGN2) associated with schizophrenia. Hum Mol Genet 20:3042-3051. CrossRef Medline

Tandon R, Nasrallah HA, Keshavan MS (2009) Schizophrenia, "just the facts" 4. Clinical features and conceptualization. Schizophr Res 110:1-23. CrossRef Medline

Tsien JZ, Chen DF, Gerber D, Tom C, Mercer EH, Anderson DJ, Mayford M, Kandel ER, Tonegawa S (1996) Subregion- and cell type-restricted gene knockout in mouse brain. Cell 87:1317-1326. CrossRef Medline

Volk DW, Lewis DA (2014) Early developmental disturbances of cortical inhibitory neurons: contribution to cognitive deficits in schizophrenia. Schizophrenia Bulletin 40:952-957. CrossRef Medline

Vreugdenhil M, Jefferys JG, Celio MR, Schwaller B (2003) Parvalbumindeficiency facilitates repetitive IPSCs and gamma oscillations in the hippocampus. J Neurophysiol 89:1414-1422. CrossRef Medline

Vullhorst D, Neddens J, Karavanova I, Tricoire L, Petralia RS, McBain CJ, Buonanno A (2009) Selective expression of ErbB4 in interneurons, but not pyramidal cells, of the rodent hippocampus. J Neurosci 29:1225512264. CrossRef Medline

Walsh T, McClellan JM, McCarthy SE, Addington AM, Pierce SB, Cooper GM, Nord AS, Kusenda M, Malhotra D, Bhandari A, Stray SM, Rippey CF, Roccanova P, Makarov V, Lakshmi B, Findling RL, Sikich L, Stromberg T, Merriman B, Gogtay N, et al. (2008) Rare structural variants disrupt multiple genes in neurodevelopmental pathways in schizophrenia. Science 320:539-543. CrossRef Medline

Wu YC, Hill RA, Gogos A, van den Buuse M (2013) Sex differences and the role of estrogen in animal models of schizophrenia: interaction with BDNF. Neuroscience 239:67-83. CrossRef Medline

Yau HJ, Wang HF, Lai C, Liu FC (2003) Neural development of the neuregulin receptor ErbB4 in the cerebral cortex and the hippocampus: preferential expression by interneurons tangentially migrating from the ganglionic eminences. Cereb Cortex 13:252-264. CrossRef Medline

Yin DM, Sun XD, Bean JC, Lin TW, Sathyamurthy A, Xiong WC, Gao TM, Chen YJ, Mei L (2013a) Regulation of spine formation by ErbB4 in PVpositive interneurons. J Neurosci 33:19295-19303. CrossRef Medline

Yin DM, Chen YJ, Lu YS, Bean JC, Sathyamurthy A, Shen C, Liu X, Lin TW, Smith CA, Xiong WC, Mei L (2013b) Reversal of behavioral deficits and synaptic dysfunction in mice overexpressing neuregulin 1 . Neuron 78: 644-657. CrossRef Medline

Zeng H, Chattarji S, Barbarosie M, Rondi-Reig L, Philpot BD, Miyakawa T, Bear MF, Tonegawa S (2001) Forebrain-specific calcineurin knockout selectively impairs bidirectional synaptic plasticity and working/episodiclike memory. Cell 107:617-629. CrossRef Medline

Zhou YX, Zhao M, Li D, Shimazu K, Sakata K, Deng CX, Lu B (2003) Cerebellar deficits and hyperactivity in mice lacking Smad4. J Biol Chem 278:42313-42320. CrossRef Medline 